\title{
UČINAK SIROMAŠTVA NA DOBROBIT I KVALITETU ŽIVOTA OBITELJI IZ PERSPEKTIVE DJECE
}

\section{SAŽETAK}

U ovom radu prikazani su rezultati kvalitativnog istraživanja koje je imalo za cilj stjecanje uvida u učinak siromaštva na dobrobit i kvalitetu života djece koja žive u uvjetima siromaštva u zajednicama različito kapacitiranim društvenim resursima. Specifično, željelo se dobiti uvid u mogućnosti ublažavanja učinaka siromaštva iz perspektive djece. Provedene su tri fokusne grupe u kojima su sudjelovali srednjoškolci iz obitelji korisnika prava na zajamčenu minimalnu naknadu. Radi se o učenicima koji pohađaju četverogodišnje (gimnazija, stručna škola) ili trogodišnje (strukovna škola) srednjoškolske programe.

Rezultati su pokazali da su djeca svjesna negativnih učinaka ekonomske krize u vlastitim životima, životima njihovih roditelja i obitelji kao cjeline. Prepoznaju specifične aspekte života u kojima doživljavaju učinke materijalne oskudice, poput osnovnih uvjeta za život, obrazovanja, zdravlja, vršnjačkih odnosa, slobodnog vremena, pristupa informacijama $i$ mogućnosti izražavanja vlastitog mišljenja i uvjerenja. Usvom životu oslanjaju se na neformalne izvore podrške te naglaša-
Izvorni znanstveni članak

Primljeno: srpanj, 2017.

Prihvaćeno: listopad, 2017.

UDK 364.65-053.2/.6

DOI 10.3935/ljsr.v24i2.181.

Marijana Kletečki Radović Lucija Vejmelka² Olja Družić Ljubotina $^{3}$ Sveučilište u Zagrebu Pravni fakultet Studijski centar socijalnog rada

Ključne riječi:

siromaštvo djece, dobrobit, siromašnije i bogatije zajednice, perspektiva djece.
Doc. dr. sc. Marijana Kletečki Radović, socijalna radnica, e-mail: marijana.kletecki.radovic@pravo.hr

2 Doc. dr. sc. Lucija Vejmelka, socijalna radnica, e-mail: Ivejmelka@pravo.hr

3 Izv. prof. dr. sc. Olja Družić Ljubotina, socijalna radnica, e-mail: olja.druzic.ljubotina@pravo.hr 
vaju odgovornost društva i države u ublažavanju posljedica siromaštva na život djece i njihovih obitelji. Specifične razlike uočene su s obzirom na to žive li djeca u siromašnijoj ili bogatijoj zajednici. Djeca iz siromašnije zajednice iskazuju još skromnije uvjete života, mogućnosti školovanja i provođenja slobodnog vremena kao i bitno smanjenu dostupnost raznovrsnih usluga. Djeca u bogatijoj zajednici naglašavaju važnost obrazovanja za izlazak iz siromaštva.

Ovo je prvo istraživanje koje je uključilo siromašnu djecu koja su iz osobnog iskustva doprinijela produbljivanju i razumijevanju spoznaja o odrastanju u siromaštvu $i$ učincima na dobrobit djeteta. Uključivanjem njihove perspektive, djeca su dobila priliku izraziti svoje mišljenje i dati »glas « o ovom, za njih i društvo nepovoljnom, socijalnom problemu.

\section{UVOD}

»...ta siromašna osoba, baš koja je siromašna osoba, može opstat. Zavisi samo kakvo je društvo..." Izjava sudionika istraživanja

Problem siromaštva djece danas je neizbježna tema koja zaokuplja stručnu i znanstvenu javnost i kao globalni i kao lokalni problem. Ekonomska kriza koja je pogodila svijet, pa tako i Hrvatsku, odrazila se na životni standard velikog broja stanovništva i dovela do porasta siromaštva, posebice siromaštva djece. Na ozbiljnost rastućeg problema siromaštva djece u razvijenim zemljama i učincima koje ekonomska kriza ostavlja na dobrobit djece, upozorio je i UNICEF svojim izvještajem o djeci u doba recesije. Pokazalo se da je recesija posebno pogodila djecu i mlade od 15 do 24 godine jer je stopa njihove isključenosti iz obrazovanja i zapošljavanja dramatično porasla u mnogim zemljama (UNICEF, 2014.).

Ekonomska kriza se i u Hrvatskoj odrazila na porast siromaštva djece. Tako je 2012. godine, po prvi put, stopa rizika siromaštva djece bila viša od nacionalne stope $^{4}$, što je trend koji se zadržao i do danas (DZS, 2014., 2016.) Rastuće siromaštvo, problemi nezaposlenosti, financijska neizvjesnost i zaduženost mnogih obitelji u Hrvatskoj dovele su do zabrinutosti za ostvarenje brojnih dječjih prava koja najviše ovise o materijalnoj situaciji u obitelji, a na koje sustavno upozoravaju Ured pravobraniteljice za djecu (Izvješća o radu pravobraniteljice za djecu od 2012. do 2016. godine ${ }^{5}$ ) i UNICEF Hrvatska (Analize stanja prava djece i žena u Hrvatskoj, 2011. i

4 Stopa rizika siromaštva djece 2012. godine bila je $22 \%$ u odnosu na nacionalnu stopu, 19,5\%. Zadnji službeni podatci za 2015. godinu pokazuju da je stopa rizika dječjeg siromaštva (0-17 godina) 20,9\%, a nacionalna stopa rizika od siromaštva 20\% (DZS, 2016.a).

5 Dostupno na: http://www.dijete.hr/index.php?option=com_joomdoc\&task=cat_view\&gid=946\&ltemid $=85$.

\section{0 članci}


2014. godine $\left.{ }^{6}\right)$. Analize stanja i rezultati istraživanja o djeci koja žive u uvjetima siromaštva u Hrvatskoj (Kletečki Radović, 2011.; Šućur i sur., 2015.) pokazuju da se radi o posebno ranjivoj skupini djece čije potrebe nisu dovoljno prepoznate i vidljive kroz postojeće sustave pomoći i podrške te da postoji nužna potreba da se politikama koje zagovaraju prava djece definiraju konkretne mjere i socijalne usluge kojima će se ublažiti ili smanjiti ovaj rastući socijalni problem.

U tom smislu, Hrvatska je donijela »Nacionalnu strategiju za prava djece od 2014. do 2020. godine« u kojoj se izdvajaju siromašna djeca kao posebno ranjiva skupina, koju je potrebno zaštititi od rizika i posljedica siromaštva te unaprijediti njihov položaj u okviru različitih sustava socijalnih politika. U strategiji se u okviru definiranih ciljeva i mjera za ublažavanje i smanjenje učinaka siromaštva na život djece navodi potreba za donošenjem akcijskog plana borbe protiv siromaštva djece s jasnim i konkretnim aktivnostima koje će omogućiti ostvarivanje definiranih ciljeva, no do sada takav plan nije donesen.

Zakon o socijalnoj skrbi (2013., 2014., 2015., 2016., 2017.) propisuje pravo na zajamčenu minimalnu naknadu kao novčanu pomoć samcima ili kućanstvima koji nemaju dovoljno sredstava za podmirenje osnovnih životnih potreba, odnosno koji žive u uvjetima siromaštva. Ova socijalna pomoć izračunava se na temelju određene osnovice za kućanstvo u cjelini (prema odluci Vlade RH iz 2014. godine, $100 \%$ osnovice iznosi $800 \mathrm{kn}$ ). Osnovica za dijete, bez obzira na starosnu dob, iznosi $40 \%$, što znači 320 kn mjesečno. Prijašnji zakoni o socijalnoj skrbi prepoznavali su razvojne potrebe djece u obiteljima korisnicima socijalne pomoći, s obzirom na dob, što znači da je osnovica za dijete do navršene 7. godine života iznosila $80 \%$ pomoći, od 7. do 15. godina života $90 \%$, a za dijete od 15 . do 18. godina, te mlađe punoljetnike u redovitom školovanju, $100 \%$ osnovice. U tom smislu važeći propis (Zakon o socijalnoj skrbi, 2013., 2014., 2015., 2016., 2017.) ne akceptira rizike života u siromaštvu za razvoj djeteta, u nesuglasju je s prioritetnim ciljevima i definiranim ranjivim skupinama djece u »Nacionalnoj strategiji za prava djece od 2014. do 2020. godine« te nije usmjeren na ublažavanje učinaka siromaštva i podršku za prevladavanje nepovoljnih okolnosti u kojima žive siromašna djeca. Iznimno, zakonodavac prepoznaje rizik samohranog roditeljstva, odnosno jednoroditeljstva, pa određuje novčanu pomoći za takvo dijete u iznosu od $55 \%$ osnovice zajamčene minimalne naknade (440 kn).

6 Dostupno na: http://www.unicef.hr/. 


\section{SIROMAŠTVO I DOBROBIT DJECE}

Ne postoji općeprihvaćen pristup konceptualizacije i definiranja pojma siromaštva (Družić Ljubotina i Kletečki Radović, 2011.; Šućur, 2014.), pa tako ne postoji ni univerzalan pristup u interpretiranju i mjerenju siromaštva djece. U najširem smislu, »dječje siromaštvo« (eng. child poverty) znači da djeca i mladi tijekom svog djetinjstva žive u lošim materijalnim uvjetima i neimaštini. Osnovna razlika u odnosu na siromaštvo odraslih je u različitim uzrocima i posljedicama koje mogu imati dugotrajan ili trajan učinak na život djeteta. Čak i kratka razdoblja deprivacije mogu dugoročno utjecati na rast i razvoj, odnosno dobrobit djeteta (Minujin i sur., 2006.; Šućur i sur., 2015.).

Danas stručnjaci i sve relevantne organizacije koje se bave djecom (UNICEF, Save the Children, CHIP, CIDA, CCF) siromaštvo djece definiraju kao višedimenzionalni koncept i u kontekstu dječjih prava, kao ih određuje »Konvencija o pravima djece« (Ridge, 2002.; Bradshaw, Richardson i Ritakallio, 2007.; Bradshaw, 2011.; Šućur i sur., 2015.). Definiranje siromaštva u kontekstu dječjih prava naglašava mogućnost ostvarivanja osnovnih građanskih, političkih, ekonomskih, socijalnih i kulturnih prava djece. Pristup dječjim pravima dominantno je prisutan u raspravama o djeci jer polazi od koncepta djeteta kao individue koja ima pravo na zaštitu svojih prava i interesa, posebno zaštitu zdravlja, prava na obrazovanje, primjeren standard življenja i prava na aktivno sudjelovanje u društvu (Redmond, 2008.).

Višedimenzionalno definiranje siromaštva polazi od tumačenja da je siromaštvo mnogo više od ekonomske prikraćenosti, odnosno da siromaštvo ne ovisi samo o dohotku, već i o dobrima i uslugama koje si osoba može priuštiti, odnosno koja su djetetu dostupna. To podrazumijeva ekonomski standard, uvjete života, zdravlje, subjektivnu dobrobit, obrazovanje, odnose djece s drugima, sudjelovanje u zajednici, rizicima kojima su djeca izložena te stupnju sigurnosti. Mogućnosti i kvaliteta života djeteta ovisi o njegovoj/njenoj edukaciji, vještinama, pristupu kvalitetnoj zdravstvenoj skrbi, dostojnim uvjetima stanovanja, sigurnosti i kvaliteti životnog okruženja (Magdi i Middleton, 2007.; Kletečki Radović, 2011.).

Ovakav pristup razumijevanja siromaštva djece omogućio je sagledavanje problema u širem konceptualnom okviru dobrobiti djeteta. Koncept dobrobiti djeteta naglašava svu složenost dječjih života i odnosa te uloge niza čimbenika koji mogu utjecati na životne situacije djece. Dobrobit se odnosi na optimalno funkcioniranje i iskustvo djeteta. Polazeći od perspektive prava djeteta, dobrobit se definira kao ostvarivanje prava i mogućnosti cjelovitog i usklađenog razvoja potencijala svakog djeteta (Ajduković, 2015.). Jordan (2006.) navodi da je koncept dobrobiti usko povezan s konceptom dječjih prava, potreba, uključivanja i materijalne dobrobiti. Ono po čemu je koncept dobrobiti drugačiji je naglašavanje emocija, iskustava, odnosa i veza djeteta s drugima.

\section{2 članci}


U izvještajima i istraživačkim studijama o djeci nalazi se različiti broj dimenzija i indikatora dječje dobrobiti (Bradshaw, Richardson i Ritakallio, 2007;; Bradshaw, 2011.; UNICEF, 2007., 2013.; Šućur i sur., 2015.). Najčešći okvir za mjerenje dobrobiti djeteta sadrži sljedeće dimenzije: (1) ekonomski status obitelji, (2) zdravlje djeteta, (3) stanovanje i lokalna zajednica, (4) obrazovanje, (5) socijalni odnosi - odnosi s obitelji i vršnjacima, (6) sigurnost djeteta, (7) rizična ponašanja, (8) slobodno vrijeme, (9) aktivno sudjelovanje u društvu, (10) subjektivna dobrobit. Kako navode Šućur i sur. (2015.), istraživanja dječje dobrobiti više se razlikuju po izboru indikatora i njihovu grupiranju, nego po izboru dimenzija.

lako se dobrobit djece ne razlikuje suštinski od dobrobiti ljudi općenito, djeca su puno više ovisna o vanjskim utjecajima (npr. kvaliteti ishrane i poticajnom okruženju za rast i razvoj), pa siromaštvo i drugi oblici deprivacije djece mogu utjecati na djecu cijeli njihov život. To naglašava i misao voditelja projekta unutar kojeg je provedeno istraživanje s djecom i mladima, a koja kaže: »Djetinjstvo je jednokratni 'prozor' u razvoj mogućnosti i učenje i propuštene mogućnosti se često teško nadoknađuju« (Ajduković, 2015.).

Jasno je da siromaštvo šteti dobrobiti djeteta. Siromaštvo je povezano s različitim nepoželjnim ishodima u djetinjstvu i odrasloj dobi. Istraživanja su pokazala da ekonomska moć obitelji ima učinke na razvojne ishode djece, kao što su zdravlje, emocionalna dobrobit, školski uspjeh u djetinjstvu te obrazovni status, razina postignute radne kvalifikacije i obrazovanosti, zaposlenosti i ekonomske uspješnosti u odrasloj dobi (Duncan i Brooks-Gunn, 1997.; White i Rogers, 2000.). Posljedice odrastanja u siromaštvu su ozbiljnije ako dijete živi u ekstremnom ili dubinskom siromaštvu, ako se radi o dugotrajnom siromaštvu ili siromaštvu u ranom djetinjstvu (Šućur i sur., 2015.).?

Koliko je siromaštvo nepoželjno i koliko može opterećivati djecu koja ga žive, ukazuju i rezultati istraživanja o mišljenju i stavovima djece i mladih u Hrvatskoj koji su pokazali da su siromašna djeca jedna od najdiskriminiranijih skupina djece u osnovnoj i srednjoj školi (UNICEF, 2008.).

Tko može dati relevantne podatke o tome kako je iz dana u dan živjeti u uvjetima siromaštva i kakvi su učinci siromaštva na dobrobit djeteta? Službena određenja i statistički pokazatelji u pravilu nude malo saznanja o realnosti/stvarnosti siromaštva. Polazeći od koncepta uključivanja i aktivnog sudjelovanja djece i mladih (Lansdown, 2010.) te uvažavajući djetetovo osobno iskustvo života kao socijalno iskustvo samo po sebi (Ridge, 2002.), razumljivo je da bi to trebala biti djeca i mladi

Više o posljedicama koje siromaštvo može ostaviti na zdravlje i tjelesni razvoj djeteta, kognitivni razvoj i obrazovna postignuća, socijalne odnose i emocionalnu dobrobit te ekonomski razvoj i perspektivu, može se naći u publikaciji Šućur i sur. (2015) »Siromaštvo i dobrobit djece predškolske dobi u Republici Hrvatskoj«. 
koji žive u uvjetima siromaštva. Konceptualni okvir učinaka siromaštva na dobrobit djeteta trebaju dati sama djeca koja imaju iskustvo života u nepovoljnim životnim uvjetima, odnosno siromaštvu i onoga što ono za njih predstavlja. Pristup uvažavanja perspektive djece te kreiranja prostora u kojima siromašna djeca imaju pravo na svoj »javni glas « sadržaj su interpretacija koncepta siromaštva djece svih relevantnih organizacija za djecu (UNICEF, CHIP, Save the Children) ${ }^{8}$ i političkih aktera koji kreiraju politike borbe protiv siromaštva (Vijeće Europe, Europska komisija, Vlada RH). ${ }^{9}$ lako postoji mogućnost da djeca, posebice ona mlađe životne dobi, ne posjeduju objektivne informacije o kućanskom dohotku, potrošnji i troškovima obitelji, ona predstavljaju važan informacijski izvor upravo kada se govori o iskustvu života u siromaštvu i učincima na njihovu dobrobit. To se osobito odnosi na iskustvo djece i mladih čije obitelji su korisnici socijalne pomoći, odnosno obitelji u dohodovno najnepovoljnijoj situaciji, što je okolnost i status koji djeca svakodnevno doživljavaju te mogu o njoj, iz osobne perspektive, relevantno govoriti. Istraživanja o siromaštvu koja uključuju djecu trebaju pretpostaviti istraživačke nacrte u kojima uzorkovanje sudionika proizlazi iz objektivnih pokazatelja siromaštva.

U promišljanju mjera i aktivnosti za ublažavanje učinaka siromaštva, važno je uzeti u obzir perspektivu mladih koji iz osobnog iskustva mogu ukazati na ona područja u kojima im je nužna podrška i pomoć društva. To je važno jer za izlazak iz siromaštva, djeca i mladi su posebno ovisni o javnoj i državnoj politici, koja im treba omogućiti pristup društvenim resursima (UNICEF, 2005.). Ulaganja u djecu, posebno ulaganja u siromašnu djecu, danas se u mnogim razvijenim društvima prepoznaju kao socijalna ulaganja koja znače učinkovito trošenje javnih sredstava (Babić, 2013.; Šućur i sur., 2015.). Pristupom koji se temelji na ideji socijalnog ulaganja osiguravaju se uvjeti koji mogu pomoći djeci i mladima da izađu iz »kruga siromaštva« i u budućnosti budu ljudi koji aktivno mogu sudjelovati u društvu i doprinositi osobnom i društvenom razvoju.

Hoće li Hrvatska usvojiti ideju ulaganja u djecu kao socijalnog ulaganja, pitanje je političke volje i konkretiziranja prioritetnih ciljeva definiranih »Nacionalnom strategijom za prava djece u Republici Hrvatskoj od 2014. do 2020. godine«.

U sklopu šireg istraživačkog projekta ${ }^{10}$ provedeno je složeno istraživanje koje se temeljilo na kvalitativnoj metodi prikupljanja i analize podataka. Formiran je širok

8 U: Minujin, A., Delamonica, E., Davidziuk, A. \& Gonzalez, E. D. (2006). The definition of child poverty: A discussion of concepts and measurements. Environment and Urbanization, 18 (2), 481-500.

9 Council of Europe Recommendation on children's rights and social services friendly to children and families - CM/ Rec (2011)12. Nacionalna strategija za prava djece i mladih u Republici Hrvatskoj od 2014. do 2020. godine.

10 Rad je nastao kao dio projekta »Indikatori dobrobiti i siromaštva djece u Hrvatskoj u doba krize: Kako prekinuti začarani krug siromaštva djece?«. Projekt je proveo istraživački tim Studijskog centra socijalnog rada Pravnog fakulteta Sveučilišta u Zagrebu uz financijsku potporu Zaklade ADRIS.

\section{4 članci}


uzorak sudionika istraživanja koji je obuhvaćao djecu i mlade koji žive u uvjetima siromaštva, njihove roditelje, stručnjake koji rade s djecom i obiteljima te ključne društvene dionike i zagovaratelje prava djece. Ovakav pristup formiranja uzorka sudionika omogućio je sagledavanje i produbljivanje razumijevanja fenomena siromaštva djece iz različitih perspektiva (Družić Ljubotina, Sabolić i Kletečki Radović, 2017.; Ajduković, Matančević i Rimac, 2017.; Ajduković, Dobrotić i Matančević, 2017.). U nastavku rada bit će prikazani rezultati koji se odnose na perspektivu djece i mladih koji žive u uvjetima siromaštva.

\section{CILJ ISTRAŽIVANJA}

Cilj ovog istraživanja bio je dobiti uvid u perspektivu i mišljenje djece i mladih o učinku siromaštva na dobrobit i kvalitetu života te specifično o mogućnosti ublažavanja učinaka siromaštva iz perspektive djece i mladih. S obzirom na to da djeca po Konvenciji o pravima djeteta imaju pravo reći mišljenje o njima značajnim temama, stvarima i pojavama koje ih se tiču, sudjelovanje djece u ovom istraživanju prilika je za razumijevanje njihovog doživljaja odrastanja u obiteljima koje žive u siromaštvu i mogućnostima ublažavanja ovog socijalnog problema. Ovo istraživanje predstavlja početne napore u razumijevanju dječje perspektive dobrobiti i kvalitete života odrastanja u siromaštvu s obzirom da istraživačkih nalaza koji produbljuju spoznaje o siromaštvu djece u Hrvatskoj do sada nije bilo. Radi se o prvom istraživanju o učincima siromaštva na dobrobit djece iz perspektive srednjoškolaca koji imaju neposredno iskustvo života u siromaštvu. Rezultati istraživanja predstavljeni su široj javnosti na završnoj konferenciji projekta u veljači 2016. godine u Auli Sveučilišta u Zagrebu (Kletečki Radović i Vejmelka, 2016.).

\section{ISTRAŽIVAČKA PITANJA}

Polazeći od cilja, istraživačka pitanja su:

1. Što djeca i mladi misle o učinku siromaštva i ekonomske krize na život djece i njihovih obitelji?

2. Kako djeca i mladi iz siromašnijih i bogatijih zajednica opisuju dobrobit djece i mladih koje žive u siromaštvu?

3. Kako djeca i mladi iz siromašnijih i bogatijih zajednica doživljavaju socijalnu podršku?

4. Koje mogućnosti ublažavanja učinaka siromaštva djece navode djeca i mladi iz siromašnih obitelji u siromašnijim i bogatijim zajednicama? 


\section{METODA}

Provedeno je istraživanje koje se temeljilo na kvalitativnoj metodi prikupljanja i analize podataka. U istraživanju su sudjelovala djeca i mladi" ${ }^{11}$ koji žive u uvjetima siromaštva. Podaci su prikupljeni metodom fokusnih grupa.

\section{Sudionici istraživanja}

U uzorak sudionika istraživanja uključena su djeca i mladi koji žive u obiteljima korisnicima zajamčene minimalne naknade. Radi se o obiteljima koje su korisnici socijalne pomoći u sustavu socijalne skrbi i koje žive u dohodovno najnepovoljnijim uvjetima. U uzorak sudionika istraživanja uključena su djeca i mladi koji žive u siromašnijoj i bogatijoj zajednici, odnosno zajednicama koje se razlikuju prema visini stope rizika od siromaštva sukladno nalazima o depriviranosti zajednica te raspodjeli rizika od siromaštva i socijalne isključenosti u $\mathrm{RH}$. $\mathrm{U}$ istraživanje je uključena jedna zajednica s niskom (9,8\%) i jedna zajednica s višom (27,4\%) stopom rizika od siromaštva (DZS, 2015., 2016.). Ovakav pristup trebao je omogućiti dobivanje uvida u učinke siromaštva na dobrobit djece u kontekstu okolinskih obilježja zajednice, koje posredno mogu ublažiti ili otežati život djeteta u siromaštvu.

Vezano uz uzrast sudionika, u uzorak su uključeni srednjoškolci, učenici prvih, drugih i trećih razreda, koji su polaznici četverogodišnjih (gimnazija, stručna škola) i trogodišnjih (strukovna škola) srednjoškolskih programa. Radi se o srednjoškolcima koji ne primaju neki oblik učeničke stipendije. $U$ istraživanju je sudjelovalo 11 djevojaka i 10 mladića.

\section{Metoda prikupljanja podataka}

U svrhu prikupljanja podataka korištena je metoda fokusne grupe. Provedene su tri fokusne grupe u kojima je sudjelovao 21 sudionik, djeca i mladi koji žive u uvjetima siromaštva. $U$ siromašnijoj zajednici provedene su dvije fokusne grupe. $U$ jednoj fokusnoj grupi okupljeno je osmero srednjoškolaca, učenika četverogodišnje srednje škole, a u drugoj, devet srednjoškolaca, učenika trogodišnje, strukovne škole. Fokusne grupe provodile su se u prostoru srednje škole. U bogatijoj zajednici provedena je jedna fokusna grupa u kojoj je sudjelovalo četvero srednjoškolaca, svi učenici četverogodišnjih srednjih škola. Fokusna grupa provodila se u prostoru

11 U radu se koristi termin djeca i mladi kako bi se istaknula dvojaka uloga sudionika u istraživanju, uloga djeteta koje živi u siromašnoj obitelji (dijete do 18. godine života prema Konvenciji o pravima djeteta) te srednjoškolaca koji dobno odgovaraju skupini mladih.

\section{6 članci}


udruge civilnog društva. Formiranje fokusnih grupa predstavljalo je značajan izazov za istraživače. $U$ bogatijoj zajednici potencijalni sudionici istraživanja nisu ni pristali na sudjelovanje, a određeni broj mladih koji su potvrdili sudjelovanje u istraživanju, nisu došli u dogovoreno vrijeme provedbe fokusne grupe. Fokusna grupa se pokušala okupiti naknadno, no u ponovnom kontaktu s roditeljima dobili smo odgovor da mladi ne žele sudjelovati $u$ istraživanju.

Fokusne grupe vođene su kao strukturirani razgovor kroz unaprijed određene tematske cjeline po pripremljenom predlošku s pitanjima. Tematske cjeline su:

1. Ekonomska kriza:

- Kako se ekonomska kriza odrazila na život mladih i na život njihove obitelji? Tko je u vašoj obitelji najviše uskraćen u svojim željama i potrebama zbog ekonomske krize?

- Kako se to odrazilo na vaše roditelje? S kojim poteškoćama se suočavaju vaši roditelji zbog ekonomskih teškoća? Koja rješenja vaši roditelji nalaze za nošenje s teškoćama ekonomske krize?

- Što bi rekao/la da tvoja obitelj i ostale obitelji lošijeg materijalnog statusa nemaju, a one boljeg materijalnog statusa imaju? Čega se sve odričete zbog ekonomskih teškoća?

2. Dobrobit djece i mladih u kontekstu siromaštva:

- Na koji način se ekonomska kriza u društvu nepovoljno odrazila u tvom životu i to na osnovne životne potrebe, školovanje, prijateljstvo i odnose $s$ vršnjacima, način provođenja slobodnog vremena, uključenost u aktivnosti svoje zajednice, tvoje raspoloženje i osjećaje, tvoje zdravlje i zdravlje članova tvoje obitelji, odnose u obitelji?

3. Socijalna podrška djeci i mladima koji žive u uvjetima siromaštva:

- Tko ti sve pomaže u životu? Kako doživljavaš podršku iz okoline?

4. Mogućnosti ublažavanja učinaka siromaštva djece iz perspektive mladih:

- Što bi ti osim materijalnih oblika pomoći moglo pomoći da ostvariš svoje planove za budućnost?

- Kako društvo/država najbolje može pomoći mladima i djeci koja žive u uvjetima siromaštva i ekonomskih teškoća?

- Što bi stručnjaci (nastavnici, socijalni radnici, liječnici, netko drugi) trebali znati o siromaštvu i ekonomskim teškoćama djece i mladih?

Razgovori u fokusnim grupama trajali su oko 90 minuta. Fokusne grupe su uz pristanak sudionika audio snimane te potom transkribirane, a nakon transkripata su audio verzije uništene.

Na fokusnim grupama sudjelovali su voditelj i suvoditelj koji je vodio bilješke razgovora i pomagao u grupnoj interakciji. U svakoj fokusnoj grupi u svojstvu voditelja ili suvoditelja sudjelovao je jedan od istraživača i autora ovog rada. 


\section{Postupak istraživanja}

Istraživanje je provedeno u razdoblju od svibnja do srpnja 2015. godine. U izboru sudionika istraživanja sudjelovali su djelatnici centara za socijalnu skrb koji su iz svoje dokumentacije o obiteljima korisnicima socijalne pomoći izdvojili učenike od prvog do trećeg razreda srednje škole koji žive u obiteljima korisnika zajamčene minimalne naknade. Stručnjaci iz centara za socijalnu skrb telefonski su kontaktirali roditelje te po unaprijed pripremljenim predlošcima zatražili suglasnost za kontaktiranje djeteta i njegovo sudjelovanje $u$ istraživanju. Ukoliko su roditelji dali svoj pristanak i broj na koji se može stupiti u kontakt s djetetom, istraživači su pristupili formiranju fokusnih grupa. $U$ telefonskom razgovoru, kao i na početku fokusne grupe, djeca i mladi su bili upoznati sa svrhom i ciljevima istraživanja te načinom prikupljanja podataka. S onima koji su izrazili svoju spremnost na sudjelovanje, dogovoreno je vrijeme i mjesto održavanja fokusne grupe. Za svako dijete koje je sudjelovalo u istraživanju predviđen je prigodan dar zahvale (paket školskog pribora) o čemu su bili prethodno obaviješteni.

Voditelji fokusnih grupa informirali su djecu i mlade o etičkim aspektima provedbe istraživanja, uključujući jamstvo povjerljivosti i anonimnosti u prikazu rezultata pod vidom označavanja pojedinačnih izjava sudionika određenom šifrom. Sudionici su usmeno dali informirani pristanak na sudjelovanje u istraživanju, čime je osigurana dobrovoljnost sudjelovanja, dok su njihovi roditelji prethodno dali pristanke o sudjelovanju njihove djece u istraživanju.

Istraživanje su provodili iskusni stručnjaci poštujući odredbe »Etičkog kodeksa istraživanja s djecom «12. Etičko odobrenje nacrta istraživanja potvrdilo je »Etičko povjerenstvo Pravnog fakulteta Sveučilišta u Zagrebu«.

\section{Obrada podataka}

Kvalitativna obrada podataka provedena je postupkom analize okvira (engl. framework analysis). Ritchie i Spencer (1994.) napominju kako je analiza okvira prikladna kada se radi o istraživanjima javnih politika. Radi se o kvalitativnim istraživanjima u kojima postoje unaprijed definirana istraživačka pitanja sa svrhom deskripcije i interpretacije određenih socijalnih problema u specifičnom okruženju kao, primjerice, u ovom radu doživljaj odrastanja u siromaštvu djece koja dolaze iz obitelji koje žive u siromaštvu. Srivastava i Thomson (2009.) naglašavaju kako je opravdano da je u ovom tipu istraživanja uzorak namjerno odabran s obzirom na

12 http://www.ufzg.unizg.hr/wp-content/uploads/2013/12/Eticki-kodeks-istrazivanja-s-djecom.pdf.

\section{8 članci}


istraživačka piranja na koja treba dati odgovor u kratkom vremenskom roku što omogućava preporuke i uvide koji mogu poslužiti donositeljima odluka i akterima socijalne politike na području siromaštva. Proces obrade podataka uključio je pet međusobno povezanih koraka po Ritchieu i Spenceru (1994.). U prvom koraku su se istraživači upoznali s građom kako bi u sljedećem koraku postavili tematski okvir. U trećem koraku su se kodirale ili indeksirale izjave djece i mladih koje su na temelju sličnosti sadržaja grupirane u pojmove koji su potom apstrahirani u kategorije. Analiza je uključila i unošenje u sheme radi dobivanja veće preglednosti rezultata. $U$ posljednjem koraku su se povezivali i interpretirali rezultati kako bi saznali perspektivu i mišljenje djece i mladih o učinku siromaštva na dobrobit i kvalitetu života. Podatke su neovisno analizirala tri istraživača koji su u posljednjem koraku usporedili analize i dobivene rezultate te uskladili istraživačke nalaze kako bi se pokušala umanjiti pristranost istraživača. ${ }^{13}$

\section{REZULTATI}

Rezultati su prikazani u okviru četiri tematska područja definirana istraživačkim okvirom: 1 . Učinci ekonomske krize i siromaštva na život djece i mladih $i$ njihovih obitelji; 2. Dobrobit djeteta u kontekstu odrastanja u uvjetima siromaštva; 3. Socijalna podrška djeci i mladima koji žive u uvjetima siromaštva i 4. Mogućnosti ublažavanja učinaka siromaštva djece iz perspektive mladih.

Kroz tematske cjeline specifično su istaknuti rezultati koji ukazuju na ono što je zajedničko svim mladima koji žive u uvjetima siromaštva, te rezultati koji ukazuju na specifične razlike između mladih koji žive u siromašnijoj i bogatijoj zajednici.

\section{Učinci ekonomske krize i siromaštva na život djece i mladih i njihovih obitelji}

Prvo definirano tematsko područje odnosilo se na učinke ekonomske krize na život mladih i na život njihove obitelji. Zasebno su prikazani učinci ekonomke krize i siromaštva na život mladih i njihovih obitelji koje izdvajaju sva djeca koja žive u uvjetima siromaštva (Tablica 1.), a zatim specifične razlike koje proizlaze iz obilježja zajednica, siromašne ili bogate zajednice, u kojima djeca i mladi žive i školuju se (Tablica 2.).

13 Dobiveni nalazi ilustrirani su izjavama sudionika koje su zbog povjerljivosti označeni šiframa (SZT- djeca i mladi iz siromašne zajednice, učenici trogodišnje škole; SZČ- djeca i mladi iz siromašne zajednice, učenici četverogodišnje škole, BZ- djeca i mladi iz bogatije zajednice). 
Tablica 1. Učinak ekonomke krize i siromaštva na mlade i njihovu obitelj - zajedničko svim mladima koji žive u uvjetima siromaštva

\begin{tabular}{|c|c|}
\hline \multicolumn{2}{|c|}{ Tema: Učinak ekonomske krize i siromaštva na mlade i njihove obitelj } \\
\hline Kategorije & Pojmovi \\
\hline \multirow{5}{*}{$\begin{array}{l}\text { Niska razina ekonomskih } \\
\text { mogućnosti }\end{array}$} & Neimaština \\
\hline & Oskudna i nekvalitetna prehrana \\
\hline & Nepriuštivost odjeće i obuće \\
\hline & Problemi u podmirivanju režijskih troškova \\
\hline & Pad životnog standarda \\
\hline \multirow{2}{*}{$\begin{array}{l}\text { Svijest o ekonomskim } \\
\text { teškoćama }\end{array}$} & Osviještenost o problemima siromaštva \\
\hline & Zabrinutost za ekonomski status obitelji \\
\hline \multirow[b]{2}{*}{ Uzdržavanje obitelji } & Uključivanje mladih u rad i u uzdržavanje obitelji \\
\hline & $\begin{array}{l}\text { Naknada za praktičan rad u strukovnom obrazovanju kao } \\
\text { »dohodak« obitelji }\end{array}$ \\
\hline \multirow{2}{*}{ Odricanje roditelja } & Uskraćivanje roditelja radi zadovoljavanja potreba djece \\
\hline & Potrebe djece su prioritet obitelji \\
\hline \multirow{4}{*}{$\begin{array}{l}\text { Narušeno zdravstveno } \\
\text { stanje roditelja }\end{array}$} & Narušavanje zdravlja roditelja \\
\hline & Stres \\
\hline & Narušeno mentalno zdravlje roditelja \\
\hline & Bolest kao rizik siromaštva \\
\hline \multirow{2}{*}{$\begin{array}{l}\text { Socijalna isključenost } \\
\text { mladih }\end{array}$} & Nemogućnost sudjelovanja u aktivnostima za djecu i mlade \\
\hline & $\begin{array}{l}\text { Povlačenje iz aktivnosti i društva koji podrazumijevaju } \\
\text { trošenje novca }\end{array}$ \\
\hline \multirow{2}{*}{$\begin{array}{l}\text { Nepovoljni obrazovni } \\
\text { uvjeti }\end{array}$} & Nemogućnost zadovoljavanja obrazovnih potreba djece \\
\hline & Ulaganje u obrazovanje samo jednog djeteta \\
\hline
\end{tabular}

Djeca i mladi koji žive u uvjetima siromaštva učinak ekonomske krize prepoznaju kroz »nisku razinu ekonomskih mogućnosti « koja se očituje kroz »neimaštinu«: »...hrana, neko vrijeme nismo imali uopće, ono ništa, baš ništa, za kupiti, tako je bilo $i$ kod bake i djeda... meni je to bilo najgore... jedan od najgorih perioda za mene..." (BZ2); »... ima one djece koja nemaju za jest, ja to znam i vidim nekad.« (BZ4), »oskudnu i nekvalitetnu prehranu«: »... kupe se naranče, i to će biti jedanput u dva tjedna, mjesec dana, ali definitivno se ne može imati nikakav kvalitetan način prehranjivanja, to 100\%, ali bitno da se ima što za jesti. Što se tiče zdravije prehrane, zakinuti smo." (BZ4), »nepriuštivost odjeće i obuće«: »... a odjeća stara... tu i tamo se nađe nešto novo, ako kupe, ali to rijetko, to po popustima traže.« (BZ2), te »probleme u podmirivanju režijskih troškova«: »... pa, Isuse, koliko to računa, oni stvarno to moraju platit...« (BZ1); »... treba platit stan, treba platit režije, treba platit ovo, treba platit ono, treba ovako, treba onako, puno stvari uglavnom...«(BZ2). Ekonomska kriza utjecala je na »pad životnog

\section{0 članci}


standarda« obitelji: »Tata bi došao s posla, uvijek bi donio pune vrećice slatkiša ili bi imali novca za kupovati robu, a sad onako baš i ne. Sad nit' radi, niti može više, tak' da ništa od toga."(SZT3); »Prije možda kad je imao posao nismo mislili na neke stvari... šta ćemo sutra, a sad..." (SZČr).

Siromašna djeca i mladi posebno su »svjesni ekonomskih teškoća« koje su prisutne u njihovim obiteljima i društvu. Oni prepoznaju »probleme siromaštva«i imaju svijest o dubini siromaštva:»Postoje obitelji koje primaju socijalnu pomoć, koje su baš ono... skoro pa nemaju ništa, a opet postoje obitelji koje ipak uz tu socijalnu pomoć ipak imaju nešto, znači opet nije ono da baš skroz su na dnu.« (BZ2). Ekonomska kriza i prisutno siromaštvo čini mlade posebno "zabrinutima za ekonomski status obitelji:: "Zabrinuta sam zato što ne znam što će biti sutra, hoćemo li preživjeti ovaj mjesec..." (BZ4); »/ onda moramo gledati svoje roditelje kako krpaju kraj s krajem i odvajaju da davaju nama za gablec, za knjige..." (SZT3).

Sudjeluju u »uzdržavanju svojih obiteljik tako što se »uključuju u rad« i zarađenim novcem i »naknadama za praktičan rad u strukovnom obrazovanju pridonose uzdržavanju obitelji«: »... radim na praksi, imamo plaću, kad god treba, ja dadnem po malo..." (SZT6); »Naravno, dala sam ja i mami i tati zato što im je trebalo za račune i sve.«(BZ1); »Ja od prakse isto dajem, ostavim sebi para koliko mi treba, ostalo dadnem njima.« (SZT1).

Djeca i mladi primjećuju učinke ekonomske krize na život njihovih obitelji kroz »odricanje roditelja« kao strategiju ublažavanja života u siromaštvu za djecu. »Roditelji uskraćuju sebe u zadovoljavanju svojih potreba« kako bi djeci osigurali ono što im treba: „Kako bi rekli, odvajaju od sebe, odvajaju od svojih usta da bi dali nama." (SZČ2); »Roditelji se najviše odriču da nama pruže što više.« (BZ5); ».. . sebi uskrate nešto da bi djeca dobila.... (SZČ8), a zadovoljavanje "potreba djece su prioritet u obitelji«, ono na što se u obitelji stavlja naglasak i u što se ulaže: »...više roditelji troše na nas." (SZT1); »Neće kupiti ništa što njima treba ili odjeća neka, prije će meni dati.» (SZČ4); »... uzimaju od sebe ako nama treba nešto kupiti.« (SZT2).

Negativne učinke krize i borbu roditelja sa životom u siromaštvu, djeca i mladi vide $u$ »narušenom zdravstvenom stanju roditelja«, te posebno ističu »poteškoće mentalnog zdravlja roditelja koje povezuju sa »stresom « i svakodnevnom borbom u prevladavanju ekonomskih teškoća: »...pa, zdravlje roditelja, mentalno zdravlje njihovo, psihički šta pokušavaju, šta pokušavaju nešto nama priuštit, sve moguće da ne bi mi bili izloženi tome svemu. (BZ3); »Mamu je to najviše pogodilo... i kičma počela i živci su otišli... mamu je to najviše pogodilo." (BZ4). Mladi prepoznaju »bolest kao značajan rizik za siromaštvo« obitelji: »... moj tata je sad u trećem mjesecu imao srčani infarkt, $i$, a ono, to je normalno da je to zbog stresa i sve, svega toga, tak da... i mama sad ima puno, sve više i više ima kad ode kod doktora, stalno je neka nova bolest, dijabetes, ovo, 
ono. A to je sve zbog stresa, normalno da stres potiče, znači računi $i$ to sve, tak da ono, zdravlje..." (BZ2), te ističu zdravlje kao vrijednost koju treba čuvati i cijeniti kada si u riziku od siromaštva: »Zdravlje je za nas najbitnije...»(SZT8).

Posljedica ekonomske krize i života u siromaštvu je i »socijalna isključenost djece i mladih « iz aktivnosti koje su njima važne, a koje uključuju kontakt s vršnjacima i razvoj određenih vještina. Tako mladi koje žive u siromaštvu ukazuju na »nemogućnost sudjelovanja u aktivnostima za djecu i mlade« koje se posebno odnose na izvanškolske aktivnosti: "Što se tiče izvanškolskih aktivnosti, mislim da smo zakinuti na neke treninge i to neko sportsko obrazovanje.... (BZ1);»Prije par godina jedna frendica me bila naučila plesti šal sa vunom. Nikad nisam mogla nastaviti jer nisam mogla nikad kupiti, dosta je skupa vuna..." (BZ4) te ističu kako se »povlače iz aktivnosti i društva koji podrazumijevaju trošenje novca«: »Sad moram prekinuti ove godine sa Step by Stepom i treninzima zbog novaca, tak' da to ću se morati ispisati." (BZ4); »...s frendicama najčešće idem samo u šetnju ili vozimo se biciklom..." (BZ1); »Mi smo uvijek družili se svi vani i to, ono, na livadi, igrali nogomet, ne znam ni ja, zezali se.« (SZČ1).

Negativne učinke vide i u »nepovoljnim obrazovnim uvjetima« za djecu i mlade iz siromašnih obitelji koje su posljedica učinaka krize i siromaštva. Nepovoljne obrazovne uvjete očituju kroz iskazivanje »nemogućnosti zadovoljavanja obrazovnih potreba djece u obiteljik: »A moraju se kupit i udžbenici, jer se mijenjaju, na primjer neki su roditelji, ne znam, digli nekakav kredit il posudili novce ili na rate.. (SZČ4); »A to se (o. a. školske knjige) od starih generacija većinom nasljeđuje..." (SZČ6) te mogućnosti podržavanja i »ulaganja u obrazovanje samo jednog djeteta«: »Nitko nije završio fakultet, svi su završili srednju školu, jedina sam ja u gimnaziji. Svi su završili strukovne škole. Ja ću nastavit' dalje na fakultet u rokovima." (BZ4); »... i to se znalo da nemaju novaca za njih i onda sada ja idem dalje sa školom..." (SZČ4).

\section{2 članci}




\section{Specifične razlike učinaka ekonomske krize i siromaštva kod mladih koji žive u siromašnijoj i bogatijoj zajednici}

Tablica 2. Učinak ekonomke krize i siromaštva na mlade i obitelj - razlike u doživljaju mladih iz siromašnije i bogatije zajednice

\begin{tabular}{|c|c|c|c|}
\hline \multicolumn{4}{|c|}{ Tema: Učinak ekonomske krize i siromaštva na mlade i obitelj } \\
\hline \multicolumn{2}{|c|}{ Mladi iz siromašnije zajednice } & \multicolumn{2}{|c|}{\begin{tabular}{|l} 
Mladi iz bogatije zajednice \\
\end{tabular}} \\
\hline Kategorije & Pojmovi & Kategorije & Pojmovi \\
\hline $\begin{array}{l}\text { Ekonomska } \\
\text { i socijalna } \\
\text { depriviranost } \\
\text { zajednice }\end{array}$ & $\begin{array}{l}\text { Socijalne naknade kao } \\
\text { osnovni prihod obitelji } \\
\text { Opća nezaposlenost } \\
\text { Izostanak komunalne } \\
\text { infrastrukture - vode }\end{array}$ & $\begin{array}{l}\text { Racionalizacija } \\
\text { života u } \\
\text { siromaštvu }\end{array}$ & $\begin{array}{l}\text { Naglašavanje } \\
\text { nematerijalnih životnih } \\
\text { vrijednosti } \\
\text { Racionalizacija } \\
\text { materijalnog statusa } \\
\text { Prilagođavanje životu u } \\
\text { siromaštvu }\end{array}$ \\
\hline Rizik gladi & $\begin{array}{l}\text { Odricanje od obroka } \\
\text { Kupovanje jeftinije hrane } \\
\text { u inozemstvu }\end{array}$ & $\begin{array}{l}\text { Obrazovanje } \\
\text { kao izlazak iz } \\
\text { siromaštva }\end{array}$ & $\begin{array}{l}\text { Strategije izlaska iz } \\
\text { siromaštva temeljene } \\
\text { na vlastitim snagama i } \\
\text { obrazovnom postignuću } \\
\text { Ulaganje u sebe kroz } \\
\text { obrazovanje } \\
\text { Više obrazovne aspiracije } \\
\text { roditelja }\end{array}$ \\
\hline $\begin{array}{l}\text { Izbor stupnja } \\
\text { obrazovanja }\end{array}$ & $\begin{array}{l}\text { Trogodišnje strukovno } \\
\text { obrazovanje } \\
\text { Obrtnička zanimanja } \\
\text { Plaćena praksa kao motiv } \\
\text { upisa škole } \\
\text { Rani ulazak u svijet } \\
\text { rada kao izbor stupnja } \\
\text { obrazovanja }\end{array}$ & & \\
\hline
\end{tabular}

Učinke ekonomske krize i siromaštva na specifičan način doživljavaju i ističu mladi s obzirom na to žive li u siromašnijoj ili bogatijoj zajednici.

Mladi iz siromašnije zajednice prepoznaju »ekonomsku i socijalnu depriviranost zajednice« u kojoj žive te tako ističu i navode svoja zapažanja koja su u skladu s pokazateljima o neravnomjernom regionalnom razvoju Hrvatske i uvjetima života u zajednicama koje imaju visoku stopu rizika od siromaštva (UNDP, 2007.; DZS, 2016.).

$\mathrm{U}$ tom smislu, mladi iz siromašnih zajednica učinke ekonomske krize i siromaštva vide u »općoj nezaposlenosti« u zajednici: »...nedostaje zapošljavanje, fali radnih 
mjesta dosta..." (SZT6); »Pa sigurno je lošije sad kad su ostali bez posla... «(SZČ8) i ističu da većina »obitelji živi od socijalnih naknada«:».. . mama ima primanja od ova dva mala brata, i od mene i sestre, kao dječji doplatak i to... « (SZT4); »l kod mene isto...« (SZT9), »Moj babo ne prima, ali ima mirovinu. (SZT6); »...dosta nas je onemogućilo to što ona (o. a. majka) ne radi, i on (o. a. otac) ima samo mirovinu. (SZČ4). Posebno se osvrću na infrastrukturna obilježja zajednice i navode »izostanak osnovnih komunalnih uvjeta za život", posebno »dostupnosti pitke vode«, s čime se obitelji te djeca i mladi nose: »...kod nas još nema vode... tu su davno napravili, te cijevi, ali još nisu proveli vodu..." (SZČ6); »l onda se moramo snalazit čak i za vodu... a te su cijevi, tu, sve, mislim u našem mjestu, cijevi su što on kaže, stavili i sve al vode nema.« (SZČr); »Nije pitka... kupovati, ili otić na izvor neki.» (SZČ4).

Siromašna djeca i mladi u siromašnijoj zajednici navode učinke krize koja se očituje u krajnjem obliku deprivacije kao što je »rizik gladi«. Mladi se »odriču obroka« tijekom dana, odnosno u vrijeme kada su u školi te racionaliziraju egzistencijalne potrebe ističući kako: »...mogu i bez gableca.« (SZT1), ili donose hranu od kuće: "Ja si nosim od kuće sendvič." (SZT7), a poteškoće u podmirivanju troškova hrane i ostalih namirnica, rješavaju odlaskom u kupovinu u »inozemstvo gdje se kupuje jeftinija hrana«: »Kruh je jeftiniji« (SZT2); »Jeftinija je hrana i odjeća, obuća, čarape, nakit, parfemi, sve..." (SZT6).

Specifično, mladi iz siromašnije zajednice, bilo da su učenici trogodišnjih ili četverogodišnjih srednjoškolskih programa, opisuju svoja, ali i iskustva druge siromašne djece u zajednici vezano uz »izbor stupnja obrazovanja«. Navode tako da mladi iz zajednica koje su ograničenih resursa daju prednost trogodišnjim, "strukovnim obrazovnim programima, »obrtničkih zanimanja«: »Ali, većinom, na primjer te djece, recimo koji su roditelji siromašni, su išli u neku trogodišnju školu.« (SZČ4), s obzirom da ona mladima omogućava "plaćenu praksu«: »... stolari i, to se znalo da nemaju novaca za njih i onda, ipak oni imaju tu naknadu koja im se plaća..." (SZČ4); »/du tu u školu zato da pomognu roditeljima.« (SZČr) i »rani ulazak u svijet rada«: »...pa ja znam i sad iz osnovne škole, dolje gdje smo mi išli... znam dosta djece koja će upisat baš stolara zbog te situacije.» (o. a. brzog završavanja škole i zapošljavanja) (SZČ8); "... ja mislim da će većina djece ići tamo gdje ima plaće, nego gdje nema. Ja mislim da će iduće godine skroz malo biti gimnazijalaca i ekonomista, a da će biti što više stolara. Ja vjerujem u to, vidjet ćete..." (SZT6).

Specifično, djeca i mladi koji žive u bogatijim zajednicama koje pružaju više mogućnosti i u kojima je stopa rizika od siromaštva niska, učinak ekonomske krize i život u siromaštvu doživljavaju tako da »racionaliziraju život u siromaštvu«: »ovi koji su iz malo siromašnijih obitelji, malo bolje vide na svijet, znaju da ne mogu sve dobiti. ...nekako bolje razumiju da ima i siromašnijih i bogatijih i mogu se bolje poistovjetiti s ljudima." (BZ4) kroz »naglašavanje nematerijalnih životnih vrijednostik: »Da, al ja bi

\section{4 članci}


rekla, barem kod mene je to pozitivno jer ću se znat snaći, i naučim više šta je vrjednije, mislim dal je vrijednije imat sto kuna u džepu ili imat dva prijatelja i biti s njima u parku. Znači neke vrednote nama siromašnijima su više razvijene." (BZ2), »racionalizaciju materijalnog statusa«: »...opet, nije čak dobro ni imat previše, jer onda ljudi postani i pohlepni... onaj koji ima puno ne voli gubit, a onaj koji imalo malo svejedno mu je dal će izgubit kad je i ovako izgubio sve, tako da..." (BZ3) i »prilagođavanje životu u siromaštvu«: »... a i mi koji smo iskusili nešto novo, teže, smo samim time malo pametniji ajmo reć. Kao znamo o čemu pričamo, nismo više onak, što bi bilo kad bi bilo." (BZ4).

Učinci života u siromaštvu ogledaju se u promišljanjima mladih iz bogatije zajednice o pronalaženju strategija za izlazak iz tog, za njih, nepovoljnog statusa. Specifično, mladi iz bogatije zajednice navode »obrazovanje kao izlazak iz siromaštva«, kao određenu mogućnost za ostvarenje životnih ciljeva i suočavanja s problemom siromaštva: »Škola je neki temelj, jel mislim sigurno će obrazovaniji čovjek naći brže, bolji posao, nego čovjek koji ima... ne znam samo osnovnu školu, zato sad završavam fino srednju školu, završit ću fakultet, da ja mogu bit miran.» (BZ2); »...ja planiram završit tu školu i ići na fakultet..." (BZ3); »Prvo, mogućnost završit školu...» (BZ1) i to kao "strategiju koja se temelji na obrazovnom postignuću i njihovim vlastitim snagama«: "cijeli moj život naučio me što je u životu najbitnije, da sam sebi pokušam osigurati ono što trebam i da si ono mogu priuštiti što želim, znači da završim školu i da se zaposlim. (BZ1) te »ulaganju u sebe« kako bi budućnost mogla biti perspektivnija za njih: »...definitivno ću ići, zbog sebe i zbog drugih. lonako s gimnazijom nemam ništa, nemam nikakav zanat završen, tako da moram ići u svakom slučaju, a i želim zbog sebe jer nemam šta od života bez fakulteta. Gdje god bih se htjela zaposliti, gdje bih neku bolju plaću dobivala, moram imati neko stečeno znanje fakultetsko, ne mogu bez fakulteta.« (BZ4).

Njihovi roditelji, iako su niskog obrazovnog statuse, imaju »visoka obrazovna očekivanja« od svoje djece i podupiru njihovo nastojanje i trud da kroz obrazovanje i stjecanje viših razina kvalifikacije otvore svoj put k životu koji nije opterećen siromaštvom: „Kad ne mogu naći posao, mislim, on nije završio osnovnu, valjda, ne znam, srednju... a njemu je ono, samo bitna moja škola.« (BZ2); »...da, oni znaju da ću ja upisati fakultet. Oni me jako, jako potiču istalno mi govore da se trebam trudit.« (BZ4).

\section{Dobrobit djeteta u kontekstu odrastanja u uvjetima siromaštva}

Kako bismo bolje razumjeli učinke siromaštva na dobrobit i kvalitetu života djece i mladih koji žive u zajednicama koje su različito kapacitirane resursima, u fokusnim grupama razgovaralo se o aspektima dobrobiti djeteta koji se odnose na 
osnovne uvjete za život, zdravlje, odnose s obitelji, odnose s vršnjacima, obrazovanje, slobodno vrijeme, sudjelovanje u zajednici, pristup informacijama, osjećaje, slobodu izražavanja vlastitog mišljenja i uvjerenja.

Tablica 3. Dobrobit djeteta u kontekstu odrastanja u siromaštvu - zajedničko svim mladima koji žive u uvjetima siromaštva

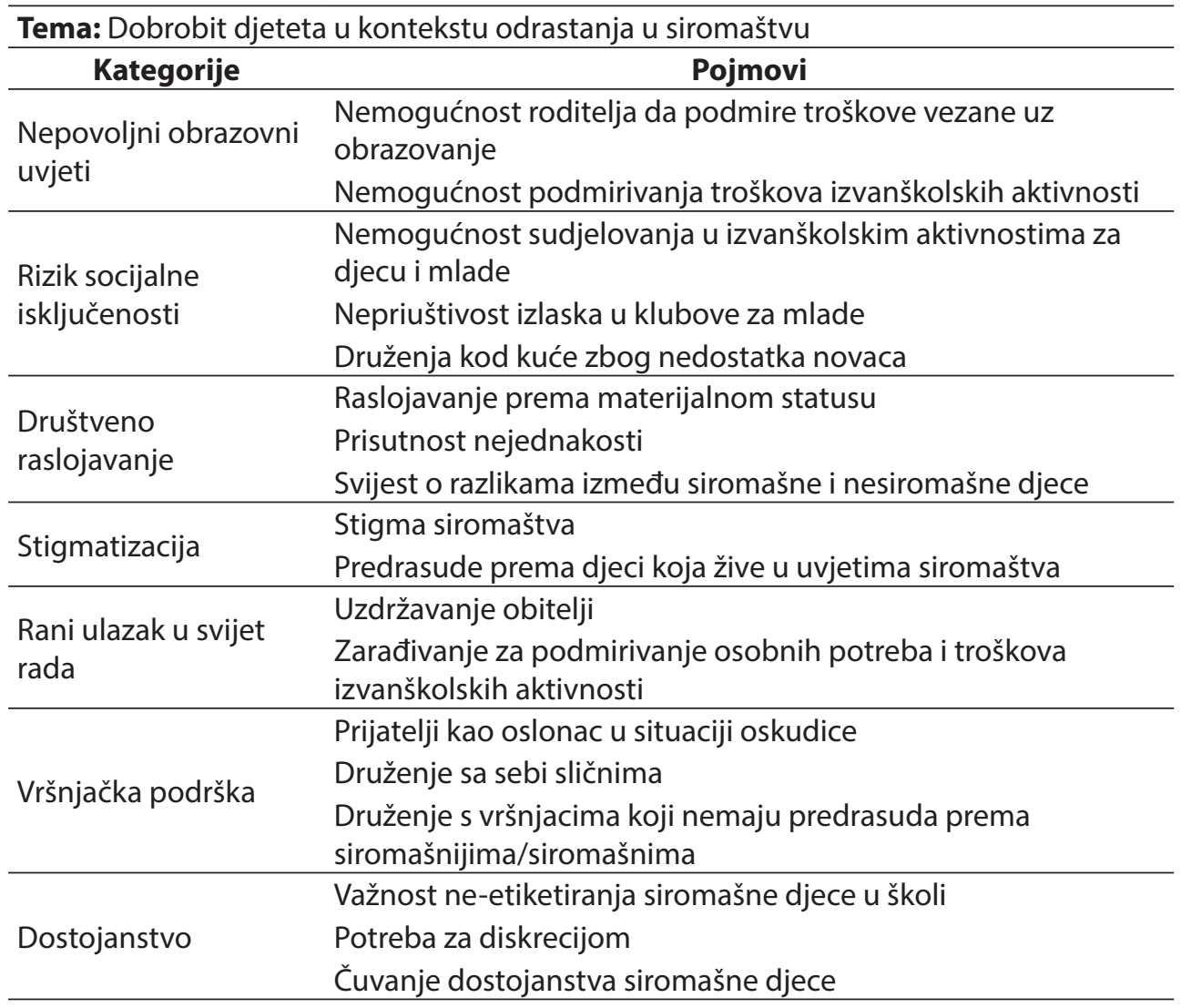

Analiza podataka pokazala je da sva djeca i mladi koji žive u uvjetima siromaštva izdvajaju određene aspekte života u kojima opisuju nepovoljne i ugrožavajuće okolnosti koje imaju utjecaj na njihovu kvalitetu života i ostvarivanje dobrobiti (Tablica 3.). Djeca i mladi posebno izdvajaju ugroženost potreba vezanih uz školovanje, odnosno navode »nepovoljne uvjete za obrazovanje«. Oni se očituju kroz »nemogućnost roditelja da podmire sve troškove obrazovanja« djeteta, od školskih knjiga i pribora, kao što su odjeća i pribor za rad u strukovnim školama: »...nema se za novu školsku torbu, knjige, bilježnice...«(SZT1); »...pribor za školu...« (SZT7), »... za kombinezon, radno odijelo..." (SZT6); »... trebali smo imati svoje škare, svoju iglu,

\section{6 članci}


pribadače...«(SZT4), dofinanciranja sadržaja koje organizira škola, a vezana su uz školske izlete, maturalna putovanja, odlaske u kazalište ili druge kulturne događaje za koje je potrebno izdvojiti novac: »...to je stvarno velik novac i... to je sad, skoro pa mjesečno primanje te jedne obitelji, i sad on bi trebao cijeli mjesec ostat bez hrane, bez ičega da ostvari djetetu to putovanje.» (SZČ8).

Mladima je posebno važno sudjelovati u aktivnostima za mlade, a navode da su uskraćeni u uključivanje jer »nisu u mogućnosti podmirivati troškove izvanškolskih aktivnostima«: »Ne znam da bi netko tko je siromašniji išao od sporta do sporta da bi vidio u čemu bi se našao..." (BZ4), "Što se tiče izvanškolskih aktivnosti, mislim da smo zakinuti za neke treninge i to neko sportsko obrazovanje...«(BZ2); »Škole stranih jezika, pa to je preskupo!« (BZ4).

Siromašni mladi ukazuju na »rizik socijalne isključenosti« kroz »uskraćenost sudjelovanja u izvanškolskim aktivnostima«:»...mi sad nemamo bašneke izvanškolske aktivnosti kojima bismo se mogli baviti... "(SZČ4), »nepriuštivost izlaska u klubove za mlade: »Pa, recimo, ovi boljestojeći mogu ići van svaki vikend, po dva tri puta, ja ne mogu, jer nemam novaca." (BZ3) i okolnosti koje ih dovode do toga da svoj društveni život organiziraju kao »druženja kod kuće zbog nedostatka novaca«: »... ono nikad nisam ni tražila novce za tak neš ni moj brat, ono, ja sam mu isto rekla da ne pita mamu... onda ono kao idemo, alajd nećemo ić nigdje..." (BZ1); »Većinom, ja samo s frendicama najčešće idem samo u šetnju ili vozimo se biciklom..." (BZ4). Djeca i mladi ukazuju na skromne mogućnosti za širenje socijalnih mreža i uključivanja u život zajednice i okruženja u kojima se mladi okupljaju, stvaraju, zabavljaju i grade društvene veze.

Sudionici istraživanja ukazuju na drugačiji položaj i status siromašne djece u društvu. Siromašni mladi primjećuju »društveno raslojavanje «»prema materijalnom statusu«: „Bogati stoje s bogatima, a ova malo niža populacija, oni su u svom društvu..." (SZT6); »Nisu toliko komunikativni, drže se po grupicama.« (o. a. bogatija djeca) (SZT4). Oni ukazuju na »prisutnost nejednakosti«: »Manje je ovih koji nemaju, ajmo reći i onda prevlada ta većina i onda ovi koji nemaju ispaštaju. (SZČ8); "Gledaju s visoka na druge ljude.... (BZ1) i imaju »svijest o razlikama između siromašne i nesiromašne djece« jer siromašna djeca nemaju: »...para« (SZT9); »...za izlaske, telefon, odjeća, za otići na kavu, novci za van... «(SZT3); ».. za vozački, tenisice, mobitel. ..«(BZ2), a »bogata« djeca imaju »...sve!" (SZT3); ». . bolji život.« (SZČ4); »Ne brinu se hoće li imati za platiti račune, hoće li ih netko uskratiti za nešto..." (SZT4).

Dobrobit djece koja žive u siromaštvu narušena je »stigmom« koja je u društvu prisutna u odnosu na siromaštvo: »Gledaju ove ljude s manje novaca kao da su oni niža klasa od njih i kao da su oni puno bolji od njih.« (SZT6), a koju mladi iskazuju kroz primijećene »predrasude prema djeci koja žive u uvjetima siromaštva«, koje se očituju kroz izbjegavanje društva siromašnih mladih: »Neće se družiti s nama.» (SZT7); »Da, 
izbjegavaju nas." (SZT3); »Kao misle, ja sam bolji od tebe, ne mo'š ti biti takav kakav ja jesam..." (SZT4).

Dobrobit i kvaliteta života siromašne djece i mladih obilježena je i »ranim ulaskom u svijet rada«. Zbog oskudnih primanja i niskog dohotka obitelji, mladi se na različite načine »uključuju u rad radi uzdržavanja obitelji«, bilo da upisuju strukovne škole u kojima za praktični dio rada imaju određenu naknadu kojom doprinose i pomažu obiteljima u podmirivanju troškova života: »... radim na praksi, imamo plaću, kad god treba, ja dadnem po malo.« (SZT4), bilo da pronalaze određene poslove kojima zarađuju kako bi mogli »podmirivati svoje osobne potrebe«: »...ja sam osjećala nekakvu potrebu, znači da sve stvari koje su bile van nekakve osnove, ja se trebam pobrinut za to... meni je to došlo nekako prirodno, bilo mi je ono što zaradim, to je moje i to je to...«(BZ4); »... počela sam preko učeničkog servisa, preko ljeta raditi... znači, nisam ni tražila od njih, a nisu ni tražili od mene, to što zaradim to je moje i ja sam si kupila šta sam htjela." (BZ1).

Važan aspekt dobrobiti djece i mladih su i vršnjački odnosi na koje su se osvrnuli i siromašni mladi u istraživanju. Oni navode različite oblike »vršnjačke podrške« i prihvaćanja od strane »prijatelja« koji su se pokazali »kao oslonac u situaciji oskudice«, ali koji su i pružali konkretnu (instrumentalnu)pomoć: »/sto tako, ima ljudi koji na primjer, ja kažem da nemam novac za gablec, zaboravila sam novce kod kuće ili nisam imala, hoćeš li mi posuditi 5 kuna, vratim ti, i uvijek ima ljudi koji će mi dati i posuditi.«(SZT4);»Oni mene uvijek počaste, znaju da nemam novaca.« (BZ4). Navode da se »druže sa sebi sličnima«: »...Držim se sjednim frendom, u istoj smo situaciji, on je isto siromašniji... (BZ4), ali i »s vršnjacima koji nemaju predrasuda prema siromašnijima/ siromašnima«: »Pa sad, u osnovnoj školi, pa i baš se nisam i previše družio... A sad u srednjoj školi isto tako, imam, imam dva, tri prijatelja koji su stvarno imućni, ali oni su tu i on je isto dobar i on pomaže.« (BZ3).

Jedan od aspekata dobrobiti djece odnosi se i na osjećaje mladih, a svi siromašni mladi posebno su istaknuli važnost očuvanja »dostojanstva siromašne djece«: »...osvijestiti da malo gledaju nas druge, tipa da malo budu obzirniji." (BZ1). Istaknuli su »važnost neetiketiranja siromašne djece u školi«: »Trebao bi imati neke određene informacije, trebao bi imat razumijevanja za takvu djecu." (nastavnik, o. a.) (SZČ̌) i "poštovanje diskrecije«: »... imamo jako diskretnu razrednicu, tako da ona to ne priča otvoreno tko ima problema. Ona to skroz diskretno. Dali su nam popust za maturalac, nisam platila punu cijenu... tako da je naša razrednica podijelila to na tri osobe iz razreda. Ja ne znam za koga još, znam da je meni ponudila." (BZ4) u situacijama kada se na neki način pomaže djeci slabijeg imovinskog statusa. U pojedinim školama njeguju se aktivnosti koje su usmjerene na prikupljanje novčanih sredstava kojima se pomaže siromašnoj djeci u podmirenju troškova povezanih s odlaskom na izlete,

\section{8 članci}


M. Kletečki Radović, L. Vejmelka, O. Družić Ljubotina: Učinak siromaštva na dobrobit i kvalitetu...

maturalna putovanja i slično te u takvim situacijama siromašni mladi ne žele biti izloženi, već naglašavaju važnost čuvanja dostojanstva i diskrecije siromašne djece.

\section{Specifične razlike u doživljaju dobrobiti kod mladih koji žive u siromašnijoj i bogatijoj zajednici}

Tijekom razgovora u fokusnim grupama o mogućim ugrozama dobrobiti djece, istaknula su se djeca i mladi iz siromašne zajednice jer su siromaštvo opisivali kroz obilježja apsolutnog siromaštva i stavljali naglasak na nemogućnost zadovoljenja »osnovnih životnih uvjeta« (Tablica 4.), posebice kao »nisku razinu komunalnih uvjeta za život i usmjerenost na podmirivanje osnovnih životnih potreba«: »Znači, prvenstveno što nama treba, bez čega ne možemo, to su voda i hrana. Uvijek prvo moramo gledati na to, nego na ostale stvari..." (SZT4); »...uvijek treba neke nove odjeće i obuće, ali neki put i ne može, treba hrane, vode i toga.« (SZT6). Navode kako obitelji nemaju osnovne infrastrukturne uvjete za život, poput kanalizacije i tekuće vode te kako je prioritet u materijalnim davanjima podmiriti egzistencijalne potrebe (»Osnovni uvjeti za život, najbitnija je hrana, voda i stanovanje, a ovo ostalo može pričekati neku drugu priliku.« (SZT7).

Ona ističu »povezanost siromaštva s negativnim utjecajem na zdravlje« i to kroz problem »nepriuštivosti lijekova za djecu i roditelje«: »l onda zdravlje... Znači, isto ti lijekovi koje treba kupiti... Fala Bogu da ja ne trebam lijekove...«(SZT6), »Ako treba kupiti neke lijekove, a ne idu na recept, pa se još mora u apoteku, pa tako uvijek treba ostavljati novac i za to.«(SZT3) te izražene svijesti o »značaju tjelesnog zdravlja«: "Zdravlje je za nas najbitnije, to je na prvom mjestu pa onda ovo ostalo... ali, zdravlje je najbitnije, da smo zdravi, da nismo bolesni.« (SZT8). Zdravlje u situaciji siromaštva predstavlja zaštitni čimbenik, osobni resurs, mogućnost da se fizički radi i da se na taj način prevladaju problemi. S druge stane, narušeno zdravlje ili bolest može biti veliki teret siromašnoj obitelji, koji nepovoljne uvjete života u siromaštvu može dovesti do neizdrživih, čega su siromašni mladi u siromašnim zajednicama iznimno svjesni.

Djeca i mladi iz siromašnije zajednice ukazuju na nisku razinu razvoja zajednice u kojoj žive i ukazuju na veliki problem »nedostupnosti usluga«. Nedostupnost usluga očituje se u »nepostojanju usluga i aktivnosti za mlade u zajednici«: »Treba imati više mogućnosti za različite aktivnosti." (SZT2); "Pa mladi gotovo da nemaju di izać u..."(SZT6); »Bilo bi bolje da ima više mogućnosti za neke sportove...«(SZT7) te su mladi pronašli rješenje u orijentiranosti prema izlascima u »susjednu državu zbog veće ponude« sadržaja »i nižih cijena«: »U ... je troduplo jeftinije.« (SZT9); »Ovdje ... sad u ovo doba ovdje nema nikoga, ne može se nikoga vidjeti na ulici... čim se prijeđe preko granice, puno ljudi.«(SZT7). Veliki problem koji navode je »ograničena dostu- 
Tablica 4. Dobrobit djeteta u kontekstu odrastanja u siromaštvu - razlike u doživljaju mladih iz siromašnije i bogatije zajednice

\begin{tabular}{|c|c|c|c|}
\hline \multicolumn{4}{|c|}{ Tema: Dobrobit djeteta u kontekstu odrastanja u siromaštvu } \\
\hline \multicolumn{2}{|c|}{ Mladi iz siromašnije zajednice } & \multicolumn{2}{|c|}{ Mladi iz bogatije zajednice } \\
\hline Kategorije & Pojmovi & Kategorije & Pojmovi \\
\hline $\begin{array}{l}\text { Ugrožavajući } \\
\text { osnovni uvjeti } \\
\text { za život }\end{array}$ & $\begin{array}{l}\text { Kućanstva bez osnovne } \\
\text { infrastrukture za život } \\
\text { (vode, kanalizacije) } \\
\text { Prioriteti u podmirivanju } \\
\text { osnovnih potreba }\end{array}$ & $\begin{array}{l}\text { »Novo« } \\
\text { siromaštvo }\end{array}$ & $\begin{array}{l}\text { Zaduženost (krediti) } \\
\text { Financijska neizvjesnost } \\
\text { Gubitak stana zbog } \\
\text { nemogućnosti otplate } \\
\text { kredita }\end{array}$ \\
\hline $\begin{array}{l}\text { Negativni } \\
\text { utjecaj } \\
\text { siromaštva na } \\
\text { zdravlje }\end{array}$ & $\begin{array}{l}\text { Nepriuštivost lijekova za } \\
\text { djecu i roditelje } \\
\text { Svijest o značaju tjelesnog } \\
\text { zdravlja }\end{array}$ & $\begin{array}{l}\text { Mogućnosti } \\
\text { škole }\end{array}$ & $\begin{array}{l}\text { Škola kao podrška djeci } \\
\text { lošijeg materijalnog statusa } \\
\text { Neosjetljivost školskih } \\
\text { djelatnika za djecu lošijeg } \\
\text { materijalnog statusa } \\
\text { Nerazumijevanje problema } \\
\text { siromaštva od strane } \\
\text { nastavnika }\end{array}$ \\
\hline $\begin{array}{l}\text { Nedostupnost } \\
\text { usluga }\end{array}$ & $\begin{array}{l}\text { Nepostojanje usluga i } \\
\text { aktivnosti za mlade u } \\
\text { zajednici } \\
\text { Ograničena dostupnost } \\
\text { interneta } \\
\text { Izlasci u susjednu državu } \\
\text { zbog veće ponude i nižih } \\
\text { cijena }\end{array}$ & $\begin{array}{l}\text { Negativni } \\
\text { aspekti } \\
\text { međuvršnjačkih } \\
\text { odnosa }\end{array}$ & $\begin{array}{l}\text { Uključenost u nasilna } \\
\text { ponašanja među djecom } \\
\text { i društveno neprihvatljiva } \\
\text { ponašanja } \\
\text { Mala vršnjačka mreža }\end{array}$ \\
\hline $\begin{array}{l}\text { Niske obrazovne } \\
\text { mogućnosti }\end{array}$ & $\begin{array}{l}\text { Izbor škole prema } \\
\text { prostornoj dostupnosti } \\
\text { Ogorčenost zbog razlika u } \\
\text { uvjetima školovanja } \\
\text { Podcjenjivanje učenika } \\
\text { strukovnih škola } \\
\text { Nerazumijevanje problema } \\
\text { siromaštva u školi }\end{array}$ & Osjećaj srama & $\begin{array}{l}\text { Neugoda i skrivanje } \\
\text { materijalnog statusa u } \\
\text { školi kako bi se izbjegla } \\
\text { stigmatizacija } \\
\text { Izbjegavanje druženja s } \\
\text { vršnjacima }\end{array}$ \\
\hline $\begin{array}{l}\text { Osjećaj } \\
\text { bespomoćnosti }\end{array}$ & $\begin{array}{l}\text { Bespomoćnost u odnosu } \\
\text { na materijalnu situaciju } \\
\text { obitelji } \\
\text { Podcjenjivanje siromašne } \\
\text { djece }\end{array}$ & & \\
\hline $\begin{array}{l}\text { Isključenost u } \\
\text { zajednici }\end{array}$ & $\begin{array}{l}\text { Neuvažavanje perspektive } \\
\text { siromašnih mladih } \\
\text { Nemogućnost sudjelovanja } \\
\text { djece i mladih u životu } \\
\text { zajednice }\end{array}$ & & \\
\hline
\end{tabular}

\section{0 članci}


pnost« računala i nemogućnost korištenja »interneta« koji je mladim ljudima nužan za učenje i komunikaciju: "Neki nemaju doma kompjuter, a treba im kompjuter..." (SZT2); »Pa znači pristup internetu, jer je to jako bitno, neki zadaci znaju bit pronađi na internetu, pa onda ako netko nema internet, to neće moć riješit." (SZČ3). Veći broj mladih u siromašnoj zajednici izjavljuje da nema internet: »...ja nemam internet." (SZČ6, SZČ3, SZT4, SZT2).

Mladi iz siromašne zajednice posebno ukazuju na »niske obrazovne mogućnosti« koje se iskazuju kroz nemogućnost izbora škole i programa obrazovanja prema interesu, sklonostima i talentima, već se škola bira prema "prostornoj dostupnosti«, odnosno djeca upisuju one programe koji se izvode u srednjoj školi u lokalnoj zajednici. Pohađanje druge škole, koja se nalazi izvan mjesta stanovanja, djeci je financijski nedostižna: »Teško bi se putovalo svaki dan, možda ne bi bilo za kartu svaki dan«. (SZT1). Siromašni mladi posebno ističu kako nemaju financijskih mogućnosti putovati u drugi grad i pohađati škole koje imaju, za njih, poticajnije obrazovne programe, bliže njihovim sklonostima i interesima: »Ja sam morala izabrati krojačku, nisam mogla ništa drugo osim toga... Mislim, mogla sam, ali teško bi mi bilo putovati i novci svaki dan za kartu... Teško bi mi bilo i financijski i sve..." (SZT2). Kao izbor, siromašnoj djeci, ostaju jedan ili dva obrazovna programa u srednjoj školi u njihovoj lokalnoj zajednici: »Ja sam iš'o, nisam mogao niš' drugo. Htio sam u ...(o. a. veći grad u županiji), ali puno je putovati $i$ košta pa sam ostao tu.» (SZT5).

Siromašni mladi opisuju svoje nezadovoljstvo statusom u školi i iskazuju »ogorčenost zbog razlika u uvjetima školovanja« kroz »podcjenjivački odnos« prema strukovnim programima i učenicima koji ga pohađaju: »Da, šumari, ekonomisti $i$ gimnazijalci skoro su svaki mjesec išli na izlet, a mi stolari i krojači ništa." (SZT3); »Na primjer, što smo mi stolari, drugačije nas gledaju. Ili govore nam da smo neodgojeni, vrijeđa nas." (SZT7); »Mi inače u ovoj školi, mi krojači i stolari... Na nas gledaju kao da smo...glupi. Upravo to.« (SZT4).

Mladi navode »nerazumijevanje škole za teškoće« koje imaju siromašne obitelji »u zadovoljavanju obrazovnih potreba« djece i mladih: »...imamo primjer škole, brat mi je pričo da su za završni rad tražili od roditelja, znači materijal taj, na tehničkoj školi, bio je tisuću kuna. Njemu roditelj nije mogao dat to i onda je došao tata tamo u školu i onda su se s profesorom posvađali i profesor uopće nije htio izać u susret, ni ništa.« (SZČ4).

Djeca i mladi iz siromašnije zajednice iskazuju »osjećaj bespomoćnosti« s obzirom na materijalnu situaciju u kojoj žive i koja ih u zajednici okružuje jer nemaju perspektivu i osjećaj da mogu nešto promijeniti: »Da, i onda se sigurno osjećamo bespomoćno, jer oni ne mogu tu ništa napravi..." (SZT8); »l onda moramo gledati svoje roditelje kako krpaju kraj s krajem i odvajaju od svoje robe da davaju nama za gablec, za knjige.« (SZT3). Iskazuju bespomoćnost vezano uz »podcjenjivanje siromašne djece» 
koja su učenici strukovnih škola: »...svi ostali, znači, ekonomisti, šumari i gimnazijalci smiju biti ispred... ali mi ne. Mi se uvijek maknemo van dvorišta škole, ali bez obzira na to, mi smo uvijek krivi, šta god da se desi tu.« (SZT3); »Uvijek je tak' bilo, nemoj pričat' gluposti!« (SZT9).

U siromašnijoj zajednici mladi ističu »isključenost iz života zajednice« i ukazuju na opći stav o nemogućnosti sudjelovanja mladih u društvu: »Ja mislim da je nepravedno što ljudi mlađi od 18 godina nemaju pravo glasa zato što... bi svi trebali imati pravo glasa, jer na sve će utjecati ta država, svi će valjda imati neke koristi od toga." (SZT6) te opisuju situacije »neuvažavanja« specifično "perspektive siromašnih mladih«: »Gotovo ništa ne pitaju nas koji smo na socijalnoj pomoći.« (SZT2); »Ne pitaju nas uopće ništa." (SZT1),»Kako oni znaju što bi nas zanimalo? Čitaju nam misli?« (SZT6); "Uvijek nama kažu, slobodno vi izrazite svoje mišljenje, i onda kad mi to kažemo, na primjer, nešto predložimo, dobro, razgovarat ćemo, vidjet ćemo. Znači, daju nam, ajmo reć,', neku nadu i onda na kraju opet ništa ne bude od toga." (SZT4).

Za razliku od njih, mladi koji žive u bogatijoj zajednici, isticali su neke druge oblike ugroze pojedinih aspekata dobrobiti. Mladi u bogatijoj zajednici govore o pojavi novih formi siromaštva tzv. »novo siromaštvo« (Šućur, 2014.) koje narušava kvalitetu njihovog života i čini ugrozu dobrobiti. Obitelji mladih suočile su se s problemima nemogućnosti zadržavanja pokrenutih poslova i »financijskom neizvjesnošću«, gubitkom posla što se očituje u nemogućnosti otplaćivanja podignutih »kredita: »/mali su svoj catering, tata je napravio veliki dug državi, idu kamate na to, morali su zatvorit poslovnicu, morali su otplatiti taj dug... (BZ2), što je posljedično dovelo do »gubitka stana zbog nedostatka novca za otplatu kredita« i odlaska u podstanarstvo: »...ja sa svojom mamom živim ko podstanar i sa sestrom, znači mi smo podstanari sad..." (BZ2). Posljedice »zaduženosti« mladi osjećaju kroz materijalnu depriviranost u svom životu i izražavaju se negativno o kreditima: »... ne želim nikad bit u kreditu, jer to u mojoj obitelji je ono, kredit je zabranjena tema. Kad netko spomene da je u kreditu, meni je osobno, osobno te osobe žao, jer znam kakvi su to problemi.«(BZ3).

$\mathrm{Na}$ aspekt dobrobiti koji se odnosi na područje obrazovanja, mladi iz bogatije zajednice posebno su naglasili mogućnost završavanja škole i stjecanje više razine obrazovanja kao jedne od strategija za izlaz iz siromaštva, a što je prikazano u ranijoj temi. Uz taj aspekt obrazovanja, oni se specifično osvrću i na druge »mogućnosti škole« u ublažavanju problema siromaštva, pa tako iskazuju kako »škola može biti podrška djeci« kroz ciljane aktivnosti koje su usmjerene direktnom pomaganju »djeci lošijeg materijalnog statusa«: »Naša škola je odlična škola jer imamo božićni sajam i svi novci koji se skupe na božićnom sajmu se daju socijalno ugroženima u školi našoj. Tako da i ja isto dobivam od škole novac. Tako sam ja skupila te tri godine za maturalac." (BZ4). No, mladi se osvrću i na manjkavosti u sustavu obrazovanja koje se očituje kroz »neosjetljivost školskih djelatnika za djecu lošijeg materijalnog statusa«: »...profesori

\section{2 članci}


kad krenu govorit, ne znam, učenik je ovakav, učenik je onakav, to ne shvaćaju... da nekad to ide iz toga kako dijete stoji, kako živi..." (BZ1) i »nerazumijevanje problema siromaštva« od strane nastavnika: »To je jedina stvar koja je manje kod njih, što ne razmišljaju, ne razmišljaju zbog čega je to tako." (BZ2).

Važan aspekt dobrobiti djeteta su i vršnjački odnosi. Mladi iz bogatije zajednice ukazali su kakav sve učinak siromaštvo može imati na vršnjačke odnose kroz »negativne aspekte međuvršnjačkih odnosa«. Mladi, posebno mladići, navode »uključenost u nasilna ponašanja među djecom«. Opisuju potrebu da se oni, ako je potrebno, fizički sukobe s onima koji ih podcjenjuju vezano uz materijalan status te kako čuvaju svoje dostojanstvo kroz neprihvatljive oblike ponašanja: »Ono što ljudi misle kad je netko u školi nasilan... mislim ja nisam nasilan, ali kad treba, jesam. Svako kad treba je nasilan... dosta nasilnika se, postaju nasilnici baš zbog tog, zato jer hoće ponizit tu osobu koja je njih ponizila, zato da ta osoba osjeti kako je njima. Rješavam to, ako se nikako ne može, fizičkim putem." (BZ2); "Učenici su nasilni... sve je to posljedica ovoga... mislim na manjak materijalne moći, na to mislim. Odnosno, ne mogu si priuštit nešto... «(BZ1). Također, govore i o »društveno neprihvatljivim oblicima ponašanja« kojima neki mladi nastoje ublažiti ili prikriti svoj nepovoljan položaj u vršnjačkim skupinama. Opisuju posezanje za krađama u školi kako bi se došlo do materijalnih stvari u kojima su zbog siromaštva uskraćeni: »/sto u školi krađe, i one su izazvane ovim stanjem... zato što dijete vidi, on ima, ja nemam, aha, pa ako ne mogu drugačije, zašto mu ja ne bi uzeo, pa da i ja imam.«(BZ2).

Siromašni mladi u bogatijoj zajednici ukazuju i na »malu vršnjačku mrežu«: »... idem kući nakon škole i kažem da imam nekog drugog posla...« (BZ2); »...neke moje prijateljice dođu k meni doma.«(BZ1) jer nisu u mogućnosti sudjelovati u izlascima i oblicima zabave koji iziskuju trošenje novca, kao što je odlazak na kavu ili sok nakon škole, u kino i sl.

Mladi iz bogatije zajednice ističu »osjećaj srama« i »neugodu« zbog siromaštva te nastoje prikriti činjenicu da žive u uvjetima siromaštva: »Bolje da se jedan smije, pa da se prestane smijat, nego da se cijela škola smije..." (BZ1). Oni žele »sakriti materijalni status« u kojem se nalaze kako bi »izbjegli stigmu siromaštva $\aleph^{14}$ što često rade tako da »izbjegavaju druženja s vršnjacima« iz škole: »Naravno, svi smo mi ono, ko razred, normalno svi se slažemo, svi smo si dobri, ali nismo svi ono baš sad da možemo svako svakom reći. Ja, recimo, mogu dvojici ili trojici u razredu reći bilo šta, a da nitko neće

\footnotetext{
14 Polovina siromašne djece i mladih koji žive u bogatijoj zajednici, a koje je socijalni radnik izdvojio u dokumentaciji centra za socijalnu skrb kao one koji odgovaraju obilježjima uzorka sudionika, nisu se željeli uključiti u istraživanje iako su pristanak na sudjelovanje dobili od svojih roditelja i ponuđena im je zahvala za sudjelovanje u obliku prigodnog dara. Prema iskazima njihovih roditelja, razlog odbijanja bio je »osjećaj srama« i izbjegavanje svakog povezivanja s činjenicom da dolaze iz obitelji korisnika socijalne pomoći i da spadaju u skupinu siromašnih mladih.
} 
ništa reći, i oni će se meni povjerit, ali ne mogu bilo kome.«(BZ2); »...ja s ovima iz škole ne idem van, kao onak imam drugog nekog posla, pa ne mogu nikad... doma sam uglavnom...«(BZ3).

\section{Socijalna podrška djeci i mladima koji žive u uvjetima siromaštva}

Svakoj osobi potreban je neki stupanj socijalne podrške kako bi se nosila s izazovima svakodnevnog života. Socijalna podrška pridonosi emocionalnoj dobrobiti, olakšava suočavanje sa stresom i obnašanje socijalnih uloga (Pećnik, 2003.), što je posebno važno kada se živi i svakodnevno nosi s problemima siromaštva. U ovom istraživanju željelo se dobiti uvid u doživljaj socijalne podrške siromašne djece i mladih te se u fokusnim grupama razgovaralo o tome tko pomaže siromašnim mladima, na koji način i kako oni doživljavaju socijalnu podršku.

Tablica 5. Socijalna podrška djeci i mladima koji žive u uvjetima siromaštva- zajedničko svim mladima koji žive u siromaštvu

Tema: Socijalna podrška djeci i mladima koji žive u uvjetima siromaštva

\begin{tabular}{ll}
\hline \multicolumn{1}{c}{ Kategorija } & \multicolumn{1}{c}{ Pojmovi } \\
\hline $\begin{array}{l}\text { Nedostatak izvora } \\
\text { socijalne podrške }\end{array}$ & $\begin{array}{l}\text { Oslanjanje na vlastite snage i mogućnosti } \\
\text { Isticanje samodostatnosti } \\
\text { Izostajanje očekivanje podrške formalnih izvora u budućnosti }\end{array}$ \\
\hline \multirow{2}{*}{$\begin{array}{l}\text { Prisutnost neformalnih } \\
\text { izvora podrške }\end{array}$} & $\begin{array}{l}\text { Članovi uže obitelji kao izvori emocionalne i instrumentalne } \\
\text { podrške } \\
\text { Članovi šire obitelji kao izvori instrumentalne podrške } \\
\text { Prijatelji vršnjaci }\end{array}$ \\
\hline
\end{tabular}

Unatoč činjenici da su za prevladavanje negativnih učinaka bilo kojeg socijalnog problema nužna rješenja i podrška društva, iz razgovora sa siromašnim mladima u ovom istraživanju, vidljivo je da ona izostaju i da mladi iskazuju doživljaj »nedostatka izvora socijalne podrške« (Tablica 5.). Oni ističu da se u svom životu "oslanjaju na vlastite snage i mogućnostik: »To je ono što, mislim barem za mene, da sve ove važne stvari sam sebi treba osiguravat (BZ2)«; »...selim se kod njega (o.a. momka), idem probat... on radi na baušteli i svaki mjesec obavezno dobije plaću.« (SZT3); »... čekam da navršim 18 i onda ću si tražiti posao (SZT3)«. Mladi ističu »samodostatnost": »...sama ću sebi pomagat, u cijelom životu, tak da ono... (BZ1)) i »nepovjerenje da će se u budućnosti moći osloniti na formalne izvore pomoći i podrške«: ».. .ja osobno nikakvu financijsku podršku ne očekujem... to bi bila dobra volja drugoga..." (BZ4);

\section{4 članci}


M. Kletečki Radović, L. Vejmelka, O. Družić Ljubotina: Učinak siromaštva na dobrobit i kvalitetu...

»...državu maknut skroz na drugu stranu...«(BZ2);»...pa ovdje se skoro ništa ne nudi..." (SZT8); »...nema ničeg što bi pomoglo, najmanje posla ovdje ima, u ovoj županiji, tko bi pomogao?!«(SZT4).

Istraživanje je pokazalo da sva siromašna djeca i mladi iskazuju prisustvo isključivo »neformalnih izvora socijalne podrške«. Siromašni mladi doživljavaju »članove uže i šire obiteljik kao one od kojih mogu dobiti emocionalnu i instrumentalnu podršku: »Roditelji i braća. Definitivno, obitelj mi pomaže najviše.» (BZ4); »Na roditelje, braću, prijatelje i to je to... «(SZČ4); »Na oca i na stariju sestru. Njoj mogu povjeriti sve, reći joj, vodi me ne na krivi put, nego na pravi, govori mi što se treba, a što ne treba..." (SZT2);»...na ujaka u Bosni... «(SZT6);»... na strica u Njemačkoj..." (SZT7) i opisuju kako im obitelj pruža podršku sada i kako će se na njih moći osloniti i u budućnosti: »... Oni mi uvijek pomognu kad trebam, na primjer, novac, a čiko mi je rekao kad završim školu, da ću ići tamo raditi kod njega." (SZT8); »Najviše roditelji, pa od njih bi i jedino očekivao pomoć, i možda od dede, mislim na obitelj, da od obitelji, i to je to. Znam da se na njih mogu oslonit uvijek i da će uvijek nešto smislit kako je i svih ovih godina, kad nemam, o bilo. Oni će uvijeknešto smislit da prebrodimo to dokne uspiju osmislit, osmislit još nešto da se vratimo kak je bilo i tak..." (BZ3).

Mladi doživljavaju »prijatelje vršnjake« kao one koji su prisutni u njihovim životima, koji im pružaju podršku i na koje se mogu osloniti: »Najbolji prijatelj, daje mi savjete... uvijek je tu kad mi treba."(SZT1).

\section{Specifične razlike u doživljaju socijalne podrške kod mladih koji žive u siromašnijoj i bogatijoj zajednici}

Analiza prikupljenih podataka ukazala je i na određene specifičnosti u doživljaju socijalne podrške kod mladih koji žive u zajednicama koje se razlikuju prema stupnju razvijenosti i visini stope siromaštva. Tako mladi koji žive u siromašnijoj zajednici opisuju socijalnu podršku kroz »konkretnu instrumentalnu podršku neformalnih izvora koji se odnose na »posuđivanje novca od prijatelja« kada im je novac potreban: »...ja kažem da nemam novac za gablec, zaboravila sam novce kod kuće ili nisam imala, hoćeš li mi posuditi 5 kuna, vratim ti, i uvijek ima ljudi koji će mi dati i posuditi." (SZT4) i na »oslonac rodbine i obiteljskih prijatelja koji žive u inozemstvu u pronalasku posla«. Mladi u siromašnijoj zajednici imaju visoka očekivanja od uže i šire obitelji te obiteljskih prijatelja, a povezana uz socijalnu podršku u budućnosti koja je usmjerena rješavanju njihove egzistencije kroz pronalazak posla i to u inozemstvu. Tijekom razgovora o doživljaju socijalne podrške, mladi iz siromašnije zajednice osvrnuli su se na obilježja zajednice i visoke stope nezaposlenosti: »... pa najviše je nezaposlenih u našoj županiji.» (SZT6)) te iskazali očekivanja pod vidom 
pružanja podrške u pronalasku posla u inozemstvu (»Tata ima neke veze u Švicarskoj i najbolje van iz države, jer tu stvarno nema ništa od života, nit' posla niti išta." (SZT3); »Najvjerojatnije bih otišo negdje dalje, u Njemačku, jer ovdje nema posla, to je rijetkost. To ako se i dobije, to nit' plaće niti ništa." (SZT8).

Za razliku od njih, mladi iz bogatije zajednice specifično ističu »emocionalnu socijalnu podršku vršnjaka« koju doživljavaju kao mogućnost »emocionalnog rasterećenja«: »...ja i on smo si prijatelji dobri, povjerimo se jedan drugom, pričamo normalno... njegova materijalna strana i moja materijalna strana, zapravo i nemaju neke veze jedna s drugom. On zna, isto ovo što ja vama govorim, on sve to zna... to mi je najbolji prijatelj i ja sam njemu najbolji prijatelj.« (BZ2)). Mladi koji žive u bogatijoj zajednici, također, navode i »dostupnost različitih formalnih izvora podrške« (instrumentalna socijalna podrška) poput »novčanih pomoći, stipendija, socijalnih usluga i podrške škole«: »Ja nisam ni znala da ...(o.a. grad) daje stipendije srednjoškolcima, to mi je rekla prijateljica prošle godine. Što se tiče stipendija, teško se dolazi do informacija, teško ih se dobiva." (BZ4); »...imamo božićni sajam u školi i svi novci koji se skupe na božićnom sajmu se daju socijalno ugroženima u školi našoj... i ja isto dobivam od škole novac..." (BZ4); »...osigurani su besplatni udžbenici.» (BZ2).

\section{Mogućnosti ublažavanja učinaka siromaštva djece iz perspektive mladih}

Posljednje tematsko područje odnosilo se na preporuke i prijedloge za ublažavanje učinaka siromaštva na djecu iz perspektive mladih te na pitanje o tome što stručnjaci, koji rade s djecom, trebaju znati o siromaštvu i ekonomskim teškoćama djece i mladih. Davanje odgovora na pitanja iz ovog tematskog područja podrazumijevalo je drugačiju razinu uključivanja sudionika u razgovor. Sudionici su svoje životno iskustvo uopćavali i na temelju svojih promišljanja, generalizirano ih pretočili u preporuke i prijedloge što je utjecalo i na postignutu razinu analize odgovora. Analiza odgovora ostala je na razini pojmova, bez pronađenih zajedničkih tema te su rezultati prikazani na nižoj razini apstrakcije u odnosu na prethodna tri tematska područja. Razlog tomu može biti i pitanje sudionicima koje je usmjereno generaliziranju iskustva, što dovodi do toga da su odgovori oskudniji u smislu bogatstva značenja, opisa iskustva i usmjereni na izricanje konkretnih preporuka i prijedloga.

Svi siromašni mladi ističu da je za ublažavanje učinaka siromaštva nužna »veća uključenost države u pomoć i podršku mladima«: »Političari, da više gledaju na ljude, nego na sebe.« (SZT3), »Definitivno bi trebala država pomoći, ne samo grad, nego država općenito.« (BZ4).

Na razini preporuka za unapređenje mjera za ublažavanje učinaka siromaštva, navode kako bi učinkovita pomoć društva i države bila kroz: (1) »povećane mogućnosti

\section{6 članci}


M. Kletečki Radović, L. Vejmelka, O. Družić Ljubotina: Učinak siromaštva na dobrobit i kvalitetu...

za obrazovanje«: »Treba imati mogućnost školovanja.« (BZ2), (2) »dostupnost informacija i mogućnost korištenja interneta«: »Svaka mlada osoba treba imati jedan kompjuter u obitelji, zbog prezentacija, radova u školi, interneta, informacija svakakvih." (BZ4), (3) »dostupnu podršku stručnjaka: »...da možemo s nekim razgovarat, savjetovati se o stvarima u životu. (SZT3), (4) »dostupnost aktivnosti slobodnog vremena kroz potpore za uključivanje u izvanškolske aktivnosti bez plaćanja«: »...više mogućnosti za različite aktivnosti..." (SZČ2); »... .mjesto za izvanškolske aktivnosti..." (SZČ4); »...otvaranje centra za mlade, mogućnost za zabavu..." (SZT4) te (5) »mogućnost aktivnog sudjelovanja mladih u zajednici«:»..gdje možeš volontirati, pomagati drugoj djeci u slobodno vrijeme. Crveni križ treba organizirat', da se može pomagati djeci u drugim županijama, da se može donirat' i za njih nešto, gdje nemaju dobre uvjete za život.« (BZ4).

\section{Specifične preporuke i prijedlozi mladih koji žive u siromašnijoj zajednici}

Specifično, mladi koji žive u siromašnijoj zajednici posebno ističu aspekte u kojima iz njihove perspektive država svojim mjerama i aktivnostima može unaprijediti dobrobit djece i mladih koja žive u uvjetima siromaštva. To su: (1) »dostupnost različitih programa obrazovanja i unaprjeđenje obrazovne infrastrukture«: »Da nam sagrade što više škola, da ljudi različitih mišljenja mogu izabrati različita zanimanja. Školu za zidare, škola za automehaničare..." (SZT6), (2) »bolja opremljenost škola« (»Škole bi trebale biti bolje opremljene.« (SZT6); (3) osiguravanje resursa za »otvaranje centra za mlade u siromašnoj zajednici «: »...da centar za mlade sagrade, da omoguće mladima da imaju gdje raditi stvari za mlade.« (SZT7); »...da se ljudi imaju gdje zabaviti, da imaju što trenirati. (SZT6), (4) »osiguravanje besplatnih udžbenika i pribora za školu«: »...besplatne knjige... školski pribor." (SZ4), (5) osiguravanje »stipendija i potpora za mlade « u siromaštvu: »Novac, stipendije, razne dotacije, svi oblici novca... «(SZT6) te (6) »mogućnost pristupa internetu i posjedovanje računala« (»...pa, znači, pristup internetu jer je to jako bitno...« (SZČ3).

\section{Uloga stručnjaka u ublažavanju učinka siromaštva iz perspektive mladih}

Siromašni mladi adresiraju »stručnjake« s kojima se susreću u svom neposrednom okruženju (»stručni suradnici u školi, nastavnici, socijalni radnici u CZSS-u, liječniciu) kao one koji mogu osnaživati, podržavati i kroz konkretne vidove pomoći pomagati siromašnim mladima kako bi imali više prilika za kapacitiranje svojih resursa i veće izglede za izlazak iz siromaštva: »Školski psiholog.« (SZČ7); »...da možemo ispričati 
neku svoju priču koja nas muči u dubini, ne vezano za školu.« (SZT3). No, mladi ističu i »važnost razumijevanja problema siromaštva« i potrebu da »nastavnici i suradnici u školi budu educirani i senzibilizirani za rad s djecom koja žive u siromaštvu:«»Pa ne mogu nam pomoć ako ne znaju kako je to. Mogu oni reć' razumijem, ne znam, a zapravo, ništa to ne znači, jer ne znaju, ne shvaćaju kako je to." (BZ4); »Možda, uključiti ih u neki seminar..."(BZ3).

Iz perspektive siromašne djece i mladih, »stručnjaci koji rade s djecom« (nastavnici, stručni suradnici u školama, socijalni radnici u centrima za socijalnu skrb, liječnici) trebali bi znati o: (1) značaju »individualiziranog pristupa i čuvanja dostojanstva kroz diskreciju prilikom pružanja pomoći i podrške« siromašnoj djeci i mladima: »Trebali bi znati da je svaki slučaj težak slučaj. Možda je samohranoj majci sjednim djetetom gore nego mojim roditeljima s četvero djece. I da bi se trebalo pomagati kako god se uspije. Ne moraju biti novci... (BZ4); »...važno je čuvati anonimnost. A ima i profesora koji otvoreno kaže."(BZ2); »... naša profesorica otvoreno kaže o problemima, o situacijama, ali nikad meni ne kaže da kažem iz svoje perspektive. Čuva mene, ali priča se o tome..." (BZ4), (2) »važnosti senzibiliziranja škola« za potrebe, probleme i izazove s kojima se nose djeca i mladi u siromaštvu i njihove obitelji: »/mali smo asistenticu u školi, došla je u 12., 1. mjesecu, tako nešto. Ona je bila s nama i pomagala nam što nam je trebalo... bila je draga gospođa... «(SZT4); »Školski psiholog nam treba da možemo razgovarat s nekim o tome što nas muči u dubini.«(SZT6), (3) »mogućnostima osnovne i srednje škole» u podršci djeci lošijeg imovinskog statusa: »Definitivno bi trebali više, javnije u školi govoriti o tim stipendijama jer mislim da se ne bi trebale stipendije prema nagradama davati, koliki ti je uspjeh u školi.« (BZ4); »....škola organizira božićni sajam i svi novci koji se skupe na sajmu se daju socijalno ugroženima u našoj školi.« (BZ4), »...instruktore za školu, nebitno za koji predmet..." (SZT3); »....savjetničar u školi..." (SZT4), (4) važnosti izjednačavanja obrazovnih šansi za djecu i mlade kroz »smanjivanje regionalnih nejednakosti«: "Sretna sam što živim u ... (o.a bogatijem gradu) da mogu imati takve prilike. Trebalo bi tako biti u svakoj županiji, takva politika na razini države. Trebalo bi besplatan prijevoz omogućiti, ili barem smanjiti te troškove i besplatne knjige svima, a ne da netko iz socijalne obitelji odustane zbog toga, ne može se školovati... djeci je na selu još teže nego tu." (BZ4); »... da imamo što više škola..." (SZT4) i (5) osigurati »kvalitetne škole i izvannastavne programe unutar škole«: »Treba imati mogućnost školovanja, više mogućnosti za različite aktivnosti u školi..." (SZT2) ; "Više školskih aktivnosti, sporta, bila bi škola zanimljivija...» (SZT4).

\section{8 članci}




\section{RASPRAVA}

Siromašna djeca i mladi, temeljem svog neposrednog iskustva, navode učinke ekonomske krize i ukazuju da se kriza nepovoljno odrazila na životne uvjete i različite aspekte života obitelji i njih, tako što je produbila siromaštvo u kojem su već bili ili ih dovela u siromaštvo. Siromašni mladi posebno ukazuju na deprivaciju u području osnovnih životnih potreba. Siromašne obitelji ne mogu osigurati djeci optimalnu prehranu, primjerenu odjeću, lijekove i primjereno stanovanje. Obitelji se hrane oskudno, a poneka djeca doživjela su periode takve neimaštine da su bila suočena i s rizikom gladi. Ovi nalazi sukladni su rezultatima kvantitativnog istraživanja o siromaštvu predškolske djece koja su pokazala visoku razinu depriviranosti djece upravo u području prehrane. Primjerice, pokazalo se da $22 \%$ roditelja romske nacionalne manjine korisnika socijalne pomoći i $10 \%$ roditelja koji su povremeni korisnici novčane pomoći nisu u mogućnosti osigurati svojoj djeci tri obroka dnevno (Šućur i sur., 2015.).

Ovi rezultati polučili su polemike u javnosti i bili poticaj za poduzimanje određenih mjera suzbijanja gladi siromašne djece. Polemike su bile usmjerene na propitivanje dobivenih nalaza i nevjerice o dubini siromaštva koja je povezana $s$ deprivacijom u području ishrane. Rezultati ovog istraživanja upravo su potvrdili i nadopunili nalaze kvantitativnih istraživanja o životnim uvjetima siromašnih u Hrvatskoj (Družić Ljubotina, 2009.; Kletečki Radović, 2011.; Šućur i sur., 2015.; Družić Ljubotina, Kletečki Radović i Ogresta, 2016.) te omogućili sagledavanje životne stvarnosti siromašne djece i mladih koji ukazuju na ugrozu osnovnih egzistencijalnih potreba i svu ozbiljnost ovog problema (»... hrana, neko vrijeme nismo imali uopće, ono ništa, baš ništa, za kupiti, tako je bilo i kod bake i djeda... meni je to bilo najgore... jedan od najgorih perioda za mene...«).

Materijalna situacija u siromašnim obiteljima je toliko nepovoljna da se mladi uključuju u rad i zarađivanje (poslovi preko učeničkih servisa, rad na praksi u strukovnom obrazovanju) kako bi doprinijeli uzdržavanju obitelji ili osigurali sebi novac (džeparac) kojim pokrivaju svoje osobne potrebe (plaćanje izvanškolskih aktivnosti, izlasci, odjeća i obuća i dr.). Rano uključivanje siromašnih mladih u rad i uzdržavanje obitelji nije rijetka pojava i opisana je u drugim istraživanjima o siromaštvu djece i mladih (Ridge, 2002.).

Mladi, posebno oni koji žive u bogatijoj zajednici, navode problem gubitka posla roditelja, nezaposlenost, kreditnu zaduženost i podstanarstvo kao posljedice učinka ekonomske krize na život njihovih obitelji. Iz perspektive kvalitativnog pristupa, ovi nalazi sukladni su analizama i rezultatima istraživanja o utjecaju krize na promjene u dubini, strukturi i profilu siromaštva (Bežovan i sur., 2015.; Šućur, 2014.; Šućur i sur., 2016.). Analize su pokazale da je ekonomska kriza nepovoljno 
utjecala na životni standard obitelji i kućanstava, došlo je do porasta siromaštva, pri čemu je izlazak iz siromaštva za one koji su već bili siromašni postao otežan, a nove skupine do tada nesiromašnih ulaze među siromašne. Ekonomska kriza je više pogodila radno aktivno stanovništvo (nezaposlene i zaposlene) i one koji o njima ovise, a to su djeca i mladi. Također je dovela do novih oblika siromaštva, tzv. »novog « siromaštva koje obilježava rastuća nezaposlenost, zaduženost i nemogućnost podmirivanja stanovanja i režijskih troškova, porasta siromaštva djece i povećanja broja građana koji žive u dubinskom siromaštvu.

Jedno od obilježja »novog« siromaštva je rast siromaštva djece čiji roditelji se suočavaju s gubitkom posla, radom bez plaće, smanjenih naknada za plaću zbog čega ne mogu podmirivati troškove obrazovanja djece (Šućur, 2014.). Mladi u ovom istraživanju na pitanje o učincima ekonomske krize na život obitelji i na pitanje o učinku na dobrobit djeteta u odnosu na aspekt obrazovanja, navode upravo poteškoće roditelja vezane uz financijsku podršku djeci u procesu obrazovanja. Posebno se osvrću na nemogućnost podmirivanja troškova vezanih uz udžbenike i pribor za školu, izvannastavnih sadržaja (izleti, kazalište, maturalno putovanje) dostupnosti i uključivanja djece i mladih u izvanškolske aktivnosti. Ovakvi nalazi sukladni su nalazima drugih nacionalnih istraživanja o siromaštvu djece, koja su također ukazala na problem roditelja u zadovoljavanju odgojno-obrazovnih potreba djece od najranije dobi (Pećnik, 2013.; Šućur i sur., 2015.).

Zanimljivo je da mladi u istraživanju ukazuju na trend ulaganja u školovanje jednog djeteta u obitelji. Mladi iz višečlanih obitelji navode kako roditelji podržavaju i ulažu u obrazovanje i stjecanje visokog obrazovanja samo jednog djeteta u obitelji, najčešće onog najmlađeg. Mladi opisuju da je ulaganje u obrazovanje olakšano s obzirom da su starija braća završila strukovna obrazovanja, zaposlila se te preuzela odgovornost za svoje uzdržavanje. Na taj način olakšavaju roditeljima školovanje najmlađeg djeteta (॥Svi su završili strukovne škole. Ja sad idem u gimnaziju... nastavit' ću dalje na fakultet u rokovima.«; »... i to se znalo da nemaju novaca za nji i onda sada ja idem dalje sa školom... «). Takvi roditelji imaju visoke obrazovne aspiracije i očekivanja da će barem jedno dijete steći visoku školsku spremu (Družić Ljubotina, Sabolić i Kletečki Radović, 2017.). Nalazi istraživanja o socioekonomskim obilježjima siromašne djece ukazuju da ona postižu lošiji akademski uspjeh, što je povezano i s niskom obrazovnom razinom njihovih roditelja (Kletečki Radović, 2011.; Matković, 2010.), ali i s roditeljskom uključenošću i utjecajem na motivaciju djeteta za postignućem. Pokazalo se da siromašni roditelji koji su brižni i uključeni u život i odgoj djeteta te brinu o strukturi dana i života mogu utjecati na veću uspješnost u njihovom akademskom postignuću (Crosnoe, Mistry i Edler, jr., 2002.; Linver, Brooks-Gunn i Kohen, 2002.). Visoka kvaliteta uključenosti podrazumijeva i visoka roditeljska očekivanja djetetova uspjeha (Hill, 2001., prema Čudina-Obradović i Obradović, 2006.).

\section{0 članci}


Siromašni mladi koji žive u bogatijoj zajednici posebno navode obrazovanje i stjecanje fakultetske naobrazbe kao kapital koji omogućava izlazak iz siromaštva. Unatoč nepovoljnim životnim okolnostima, depriviranosti u posjedovanju pribora i uvjeta za školovanje te malim ili nikakvim mogućnostima roditelja za potporu obrazovanju, ovi mladi ulažu napore i motivirani su za uspješno završavanje srednje škole i upis na fakultet. Svakako, u tome doprinose i resursi zajednice, odnosno veći broj socijalnih i drugih usluga koje osigurava lokalna samouprava, a koje ublažavaju učinke siromaštva obitelji (besplatan prijevoz, paketi hrane, pokrivanje režijskih troškova i dr.). Nalazi istraživanja o obrazovnim postignućima djece koja žive u uvjetima siromaštva pokazuju ranjivost siromašne djece jer je manje vjerojatno da će pohađati studij i steći visoko obrazovanje te imaju veći rizik ispadanja iz srednjoškolskog obrazovanja (Baturina, Berc i Majdak, 2014.; Matković, 2010.; UNDP, 2009.). Stoga je važno pronaći način kako osnažiti i podržati siromašnu djecu u obrazovanju, posebice onu koja iskazuju interes prema školovanju i imaju obrazovne aspiracije, bilo za stjecanje radne kvalifikacije kroz strukovno obrazovanje, bilo za stjecanje višeg i visokog stupnja obrazovanja.

Obrazovanje se smatra jednim od ključnih elemenata za socijalno uključivanje svih ranjivih skupina, tako i osoba koje žive u siromaštvu. Obrazovanjem i stjecanjem viših stupnjeva kvalifikacije otvara se mogućnost zapošljavanja i smanjuje opasnost ostajanja u »začaranom krugu« siromaštva (UNDP, 2009.; Wolf, 2007.). Posebno je važno omogućiti siromašnoj djeci pristup kvalitetnom obrazovanju i to strukovnom obrazovanju te višem i visokom obrazovanju. Obrazovanje je ključno područje intervencija u životu djece (Ridge, 2002.) s obzirom na to da u obrazovnim ustanovama djeca imaju prilike usvajati nova znanja i širiti spoznaje, razvijati vještine i unapređivati svoja životna iskustva. Ako su iskustva siromašne djece vezano uz obrazovni proces i odnose s drugima u školi pozitivna, ako su uključena u »život škole«, veća je vjerojatnost da će biti motivirana za nastavak školovanja i da će na obrazovanje gledati kao na mjesto i prostor kroz koji se mogu realizirati i ostvariti životne ciljeve. Ranija istraživanja provedena u Hrvatskoj ukazuju na nejednakosti obrazovnih šansi i pokazuju otežanu mobilnost siromašnih mladih u obrazovnom procesu (Matković, 2010.; UNDP, 2009.). Mladi u ovom istraživanju koji žive u siromašnijoj zajednici, a koja je i sama opterećena visokom stopom siromaštva, ekonomskom nerazvijenošću i skromnim infrastrukturnim i društvenim resursima, upravo su ukazali na određene probleme u dosizanju višeg stupnja obrazovanja i odabira obrazovnog programa za koji su mladi imali interes i bili motivirani. Siromašne obitelji često nemaju mogućnost financirati i podržati obrazovanje svoje djece u skladu s njihovim interesima. Siromašni mladi ograničeni su na obrazovne resurse zajednice u kojoj žive (obrazovne programe koji se nude u lokalnoj srednjoj školi) jer roditelji ne mogu financirati putovanje do nekog drugog mjesta $u$ 
kojem se nalaze srednje škole s većim izborom programa i smjerova ili financirati školovanje u drugom gradu ili županiji. Stoga, siromašni mladi upisuju prostorno dostupne srednjoškolske programe iako uglavnom nisu intrinzično zainteresirani za zanimanje koje će steći završavanjem škole. Često se radi o zanimanjima koja se ne traže na tržištu rada. To se posebno odnosi na strukovno obrazovanje i strukovne programe koji nisu usklađeni s tržištem rada (Miličević i Dolenec, 2009.). Na taj način siromašni mladi koji završavanju takve programe nisu konkurentni na tržištu rada i u visokom su riziku od nezaposlenosti u budućnosti, a time i ostajanja u siromaštvu te su u visokom riziku ovisnosti o sustavu socijalne skrbi. U Nacionalnoj strategiji za prava djece od 2014. do 2020. godine upravo se upozorava na opisanu situaciju: »dosadašnje centralizirano upravljanje školama uz decentralizaciju u financiranju pokazalo je svoje negativne učinke upravo na osiguravanju jednakog pristupa obrazovanju, pa za posljedicu imamo nejednak položaj učenika koji se školuju u različitim općinama, gradovima i županijama« (Vlada $\mathrm{RH}, 2014$.).

Mladi iz ovog istraživanja prepoznaju poteškoće vezane uz izbor škole prema prostornoj dostupnosti i izražavaju svoju ogorčenost zbog nejednakosti u dostupnosti obrazovanja, iskazuju bespomoćnost u odnosu na školovanje. Oni navode i strategije rješavanja tog problema i to tako da vide rješenje u odlasku u inozemstvo. Strategije izlaska iz siromaštva za mlade koji žive u zajednici koja je nerazvijena i ne nudi potencijal za zapošljavanje, te završavaju strukovno obrazovanje, jesu odlazak iz zemlje u potrazi za poslom. Ovakav trend posebno je zabrinjavajući s obzirom na svu ozbiljnost demografskih promjena u Hrvatskoj i iseljavanja velikog broja mladih koji zbog rizika od siromaštva rješenje pronalaze u odlasku u ekonomski poticajnija i perspektivnija društva (Akrap, 2015.).

U ovom istraživanju siromašni mladi govorili su o učinku siromaštva na pojedine aspekte dobrobiti djeteta. Zanimljivo je da su mladi iz siromašnije zajednice na pitanje o učinku siromaštva na zdravlje iskazali depriviranost obitelji u mogućnosti osiguravanja lijekova u slučaju bolest te istaknuli zabrinutost i učinke siromaštva na mentalno i tjelesno zdravlje roditelja. Svi siromašni mladi uočavaju posljedice ekonomskog pritiska na zdravlje roditelja koje se manifestira u kardiovaskularnim bolestima, karcinomima i poteškoćama mentalnog zdravlja. Ovakvi nalazi u skladu su s drugim istraživanjima o zdravlju roditelja koji žive u siromaštvu koja pokazuju povezanost psihičkog i tjelesnog zdravlja s objektivnom i subjektivnom financijskom deprivacijom, odnosno siromaštvom (Družić Ljubotina, Kletečki Radović i Ogresta, 2016.; Šućur i sur., 2015.).

Siromaštvo posebno negativno utječe na slobodno vrijeme i uključenost mladih u život zajednice. Nalazi istraživanja pokazali su da mladi ne mogu sudjelovati u aktivnostima slobodnog vremena ili izvanškolskim aktivnostima jer nemaju financijska sredstva kojima bi ih mogli platiti. Roditeljima je skupo i nedostupno

\section{2 članci}


plaćati školu stranih jezika, sport ili ples. Nemogućnost sudjelovanja u izvanškolskim aktivnostima, u druženju s vršnjacima u aktivnostima koji iziskuju novac (odlazak u kino, klub i sl.) dovodi mlade u rizik socijalnog isključivanja. Siromaštvo je često povezano s isključenošću iz različitih područja društvenog života, što dovodi do nepostojanja socijalnih veza i obesnaženosti (Družić Ljubotina i Kletečki Radović, 2011.). No, moguće je biti siromašan, ali ne i socijalno isključen (Abela i Berlioz, 2008.), na što upućuju nalazi ovog istraživanja. Naime, mladi navode određene oblike uključenosti u vršnjačke odnose, izlaske, no oni su ipak određeni financijskim mogućnostima i resursima u zajednici. Tako da mladi provode vrijeme družeći se s uskim krugom prijatelja kod kuće ili izlaze u park, šetnje, odnosno prakticiraju izlaske koji ne podrazumijevaju trošenje novca.

Mladi iz siromašnije zajednice, a koji žive u pograničnom području, navode da izlaze u susjednu državu jer je tamo sve jeftinije, kako za izlaske, tako i za nabavljanje kućanskih potrepština. U tom smislu, može se postaviti pitanje, imaju li mladi široku mrežu prijatelja i vršnjaka ili se radi o uskom krugu mladih koji imaju slično životno iskustvo, odnosno također žive u siromaštvu? Također, nude li zajednice sadržaje za djecu i mlade koji su univerzalni, kao npr. centar za mlade, a u kojima bi mladi imali mogućnosti sudjelovati i kreirati njima zanimljive programe te značajnije biti uključeni u život zajednice? Mladi iz siromašnije zajednice posebno upozoravaju na »siromaštvo« usluga u zajednici za mlade i nemogućnost uključivanja u organizirano i kreativno provođenje slobodnog vremena za mlade.

Mladi u istraživanju svjesni su društvenog raslojavanja (»Bogati stoje s bogatima, a ova malo niža populacija, oni su u svom društvu....) i upućuju na to da se u društvu formiraju društveni krugovi prema sličnim obilježjima, a jedan od njih je i materijalni status. Siromaštvo je obilježje koje je povezano s nedostatkom društvene moći i društvenom obesnaženosti (Kletečki Radović, 2008.). Stručnjaci koji se bave područjem siromaštva upozoravaju na to da »siromašni osjećaju da njihov dignitet nije prepoznat i poštovan u društvu, da zbog toga osjećaju da ih se neće čuti ili slušati. Mogu se osjećati beskorisnima i kao da nemaju mjesto u društvu« (Abela i Berlioz, 2007.: 93). To su pokazali nalazi ovog istraživanja. Mladi siromašni iskazali su svoj osjećaj nepripadnosti društvu, osjećaj bespomoćnosti i nepoštovanja te jasno u preporukama za ublažavanje učinaka siromaštva istaknuli važnost čuvanja dostojanstva mladih i neetiketiranja.

Zanimljivi rezultati povezani su s iskazima o aspektima međuvršnjačkih odnosa. Vršnjački odnosi iznimno su važni za djecu i mlade. Ulaskom u adolescenciju vršnjačke interakcije dobivaju na značaju i vršnjačka grupa postaje važan dio života mlade osobe. Zadovoljstvo vršnjačkim odnosima kod djece i mladih pridonosi njihovom općem zadovoljstvu životu te pozitivnom razvoju slike o sebi (Klarin, Proroković i Šimić Šašić, 2010.). Istraživanja pokazuju kako su negativni aspekti vršnjačkih odnosa, poput uključenosti u nasilna ponašanja, važan indikator dobrobiti djece (Bradshaw, 
2015.; UNICEF, 2007.). Poteškoće u interakcijama s vršnjacima, poput nasilja među djecom, mogu ostaviti na djecu i mlade koji su u nasilna ponašanja uključena, brojne i ozbiljne posljedice (Olweus, 1998.). Mladi u ovom istraživanju spomenuli su svoja izolirana iskustva nasilnog ponašanja pod vidom obrambene reakcije čuvanja vlastitog dostojanstva. Navodili su i saznanja o nekim drugim siromašnim mladima koji posežu za krađom kako bi prisvojili dobra koja nemaju te ih pokušali opravdati slabim materijalnim statusom i nejednakostima među vršnjacima. Život u siromaštvu predstavlja dodatan rizik za vršnjačko nasilje među djecom i društveno neprihvatljiva ponašanja. Istraživanja su pokazala da najviše vršnjačkog nasilja doživljavaju mladi slabijeg materijalnog statusa i to od strane vršnjaka koji žive u obiteljima višeg materijalnog statusa (Rajhvajn Bulat i Ajduković, 2012.).

S obzirom da siromaštvo na odrastanje djeteta ostavlja brojne moguće posljedice o kojima je bila riječ ranije, ukoliko je dijete uključeno u vršnjačko nasilje ili se društveno neprihvatljivo ponaša, to predstavlja dodatan kumulativan negativan utjecaj na dobrobit djeteta ili mlade osobe.

Važan aspekt dobrobiti djeteta je i pristup informacijama. Mladi u istraživanju naglasili su važnost interneta za pristup informacijama, ali i za mogućnost komuniciranja i održavanja veza uobičajenih u suvremenom društvu. Prednosti interneta za djecu i mlade su brojne. Internet omogućava olakšanu komunikaciju, služi za edukativne svrhe te općenito za brže, jednostavnije i lakše prenošenje informacija. Virtualna komunikacija danas je prisutna u svim dobnim skupinama. Državni zavod za statistiku (2016.b) navodi da je u Hrvatskoj primijećen porast korisnika interneta te da ga najviše koriste mladi od 16 do 24 godine. No, podaci pokazuju kako $23 \%$ kućanstava u Hrvatskoj nema internetski priključak, što nije zanemariva brojka. Kao razlozi se navode socijalno ekonomski status te ograničena dostupnost zbog previsoke cijene usluga i potrebne opreme, nedostupnost usluge na lokaciji, nedostatno znanje za služenje internetom te nepostojanje potrebe za korištenjem interneta. Navedeno upućuje da određeni broj djece u Hrvatskoj odrasta bez pristupa internetu u vlastitim kućanstvima.

Socijalna podrška uže i šire okoline i percepcija da nas drugi vide kao važne te da nas podržavaju u ostvarivanju osobnih ciljeva jedan je od značajnih čimbenika u zaštiti dobrobiti djeteta (Wright i Masten, 2006.). Djeca koja imaju čvršću mrežu podrške mogu se bolje nositi sa životnim izazovima i lakše prilagoditi društvu u kojem žive. Neformalna socijalna podrška između članova obitelji i prijatelja čini "središnji sustav podrške«, a kada takvog sustava nema ili je oslabljen, osobe trebaju podršku »izvana«, odnosno formalne izvore socijalne podrške (Pinkerton i Dolan, 2007.). Siromašne obitelji suočene s nedostatkom materijalnih, egzistencijalnih sredstava za život često se oslanjaju na formalne izvore podrške, državni i lokalni sustav socijalne skrbi, organizacije civilnog društva i vjerske organizacije (Šućur i sur., 2016.).

\section{4 članci}


Unatoč tomu, siromašni mladi u ovom istraživanju, kao sustav socijalne podrške sada i u budućnosti, isključivo navode članove uže i šire obitelji. Zanimljiv nalaz ovog istraživanja je i doživljaj nedostatka izvora socijalne podrške, odnosno isticanje samodostatnosti mladih i isticanje da se jedino mogu osloniti na vlastite snage i mogućnosti. Oni kroz prijedloge za unapređenje položaja siromašnih mladih navode potrebu da se država i društvo značajnije uključi u podršku siromašnima, ali ne izdvajaju formalne izvore pomoći kao one od kojih oni očekivano mogu dobiti podršku. Ovakav nalaz može upućivati na percepciju mladih o nedovoljno prepoznatom problemu siromaštva djece u našem društvu i nedovoljno učinkovitim i konkretnim mjerama kojima se djeluje na ublažavanje ovog socijalnog problema. lako u Nacionalnoj strategiji za prava djece u Republici Hrvatskoj za razdoblje od 2014. do 2020. godine (Vlada RH, 2014.) kao jedan od prioritetnih ciljeva navodi se osiguravanje potrebne razine financijskih sredstava za ostvarivanje prava sve djece u vrijeme gospodarske recesije.

\section{METODOLOŠKA OGRANIČENJA I PREPORUKE ZA DALJNJA ISTRAŽIVANJA}

Ovo kvalitativno istraživanje omogućilo je stjecanje uvida u stvarnost života mladih u uvjetima siromaštva te predstavlja doprinos razumijevanju učinaka siromaštva na dobrobit djece kao nadopuna dostupnim statističkim pokazateljima i nalazima kvantitativnih istraživanja.

U razumijevanju i interpretiranju rezultata te u planiranju i provedbi budućih istraživanja, važno je osvrnuti se i na određena metodološka ograničenja istraživanja.

Ovo kvalitativno istraživanje temeljilo se na fokusnoj grupi kao metodi prikupljanja podataka. Fokusne grupe provode se u nizu kako bi se dobio raspon mišljenja i iskustava sudionika o istraživanoj temi te se fokusne grupe ponavljaju sve dok se ne ustanovi kako novim grupama ne stječemo nove niti produbljujemo postojeće nalaze (Milas, 2009.). U ovom istraživanju provedene su tri fokusne grupe, koje s obzirom na unaprijed predviđena obilježja i sastav sudionika istraživanja, nisu omogućile postizanje teorijske zasićenosti (Onwuegbuzie i sur., 2009.). U budućim istraživanjima siromaštva djece i mladih koja žele proširiti spoznaju o učincima siromaštva na dobrobit djece u kontekstu okolinskih obilježja zajednice i srednjoškolskog programa koji pohađaju, potrebno je planirati veći broj fokusnih grupa kroz koje bi se mogle iscrpiti teme i iskustva mladih te dobiti cjelovitiji uvid u život siromašnih mladih $\mathrm{s}$ obzirom na karakteristike sredine u kojoj žive i obrazovnog programa koji pohađaju.

$U$ istraživačkom nacrtu planirano je provesti veći broj fokusnih grupa s mladima koji žive u siromaštvu, a prema unaprijed definiranim obilježjima sudionika koja su 
se odnosila na status učenika srednje trogodišnje ili četverogodišnje škole te života u zajednici s niskom i višom stopom rizika od siromaštva (siromašnijoj ili bogatijoj zajednici). No, unatoč nastojanjima socijalnih radnika i provoditelja istraživanja da se okupe potencijalno odabrani mladi kao sudionici u fokusnim grupama, to nije bilo moguće. U postupku formiranja fokusnih grupa susreli smo se s velikim odbijanjem sudjelovanja mladih koji žive u bogatijoj zajednici, a učenici su strukovnih škola. Prema navodima njihovih roditelja, razlog odbijanja sudjelovanja bio je sram i izbjegavanje bilo kakvog povezivanja sa siromaštvom i identificiranja kao siromašne mlade osobe. Roditelji koji su kontaktirani za sudjelovanje navodili su sljedeće: »ne želi sudjelovati, njega je sram... znate, on ne želi da se zna da smo mi korisnici socijalne pomoći... molim vas da me razumijete, to je jače od svega... . ${ }^{15}$.

Zbog navedenog, u bogatijoj zajednici provedena je samo jedna fokusna grupa u kojoj su sudjelovali mladi, učenici četverogodišnjih programa srednje škole. Moguće je pretpostaviti da je razlog odbijanja sudjelovanja ili nedolazak na provedbu istraživanja posljedica osjećaja stigme te da trogodišnje obrazovanje za mlade koja odrastaju u uvjetima siromaštva predstavlja dodatnu stigmatizaciju. Mladi koji su se u bogatijoj zajednici odazvali i sudjelovali u istraživanju su učenici koji u školi postižu jako dobar uspjeh te se samoaktualiziraju kroz obrazovno postignuće, što svakako predstavlja zaštitni čimbenik i doprinosi otpornosti siromašnih mladih.

Također, problem okupljanja sudionika istraživanja u bogatijoj zajednici može predstavljati i predviđeno mjesto održavanja fokusnih grupa. U bogatijoj zajednici siromašni mladi pozivani su da se okupe u prostoru organizacije civilnog društva i dolazak na fokusnu grupu ovisio je isključivo o njihovoj intrinzičnoj motivaciji za sudjelovanje u istraživanju. Polovica pozvanih sudionika koji su prethodno pristali na sudjelovanje nije se u dogovoreno vrijeme pojavila na provedbi fokusne grupe. U siromašnoj zajednici, fokusne grupe održavale su se u prostoru škole, nakon završetka nastave, što predstavlja određeno zadano okruženje u kojem je mladima teže izraziti nedobrovoljnost za sudjelovanje u istraživanju. Sigurno je to bio jedan od razloga zašto u siromašnoj zajednici nismo imali poteškoća u okupljanju fokusne grupe.

Samo okupljanje sudionika mladih i analiza prikupljenih podataka pružili su značajne metodološke spoznaje za daljnja istraživanja u ovom području. Ovakvo iskustvo, ali i dobiveni rezultati u ovom istraživanju o potrebi čuvanja diskrecije i dostojanstva mladih u siromaštvu te na svu ranjivost koju su iznijeli siromašni mladi, navodi na promišljanje o još osjetljivijem istraživačkom pristupu i načinima pozivanja siromašnih na uključivanje u istraživanje te osiguranja povjerljivosti.

Iskustvo provedba fokusnih grupa sa siromašnim mladima, koji spadaju u

15 Bilješke prikupljene u postupku istraživanja i zabilježene u obrascu o načinu provođenja istraživanja.

\section{6 članci}


ranjivu skupinu, svakako predstavlja metodološki i etički izazov (Čorkalo Biruški, 2014.). U tom smislu, intervju, kao metoda prikupljanja podataka koja se koristi u istraživanju socijalno osjetljivih tema, bila bi primjerenija metoda u kvalitativnim istraživanjima koja uključuju siromašne mlade.

Navedena ograničenja upućuju kako u budućim istraživanjima treba kvalitetno planirati na koji način pristupiti siromašnoj djeci i mladima jer, iako je ovo istraživanje uključilo brojne etičke norme s ciljem ne stigmatiziranja, mladi su se ipak teško odlučili za sudjelovanje.

\section{ZAKLJUČAK}

Tri su zajednička cilja u zemljama EU-a u pogledu dječjeg siromaštva (Europska komisija, 2013.). Prvo, osigurati da djeca odrastaju u obiteljima s dovoljno materijalnih resursa da mogu zadovoljiti osnovne životne potrebe, zatim osigurati da djeca imaju pristup uslugama kako bi imali šansu razviti svoje potencijale te promicati sudjelovanje djece u društvu.

Ovo istraživanje imalo je za cilj iz perspektive djece i mladih dobiti uvid u realnost života u siromaštvu, steći uvid u mogućnosti i poteškoće siromašnih obitelji da zadovolje osnovne potrebe svoje djece. Pokazalo se da su siromašna djeca materijalno deprivirana kako u egzistencijalnim, tako i u drugim aspektima života koji utječu na njihovu dobrobit. Pokazalo se da je učinak krize i siromaštva na život djece i mladih drugačiji u odnosu na regionalnu (ne)razvijenost Hrvatske. Djeci i mladima nedostupne su usluge, posebno one vezane uz obrazovanje i mogućnost aktivnijeg sudjelovanja u društvu. Također, ovo je istraživanje imalo za cilj uključiti siromašne mlade i dati im glas. Polazeći od tzv. »treće misije« akademske zajednice, pokušalo se temeljem novih spoznaja o posljedicama dječjeg siromaštva i kontinuiranog življenja u riziku od siromaštva, potaknuti na promišljanje o konstruktivnim oblicima ublažavanja ovog socijalnog problema (Ajduković, 2016.).

Ovim istraživanjem i projektom u cjelini, pokušalo se obratiti stručnoj i znanstvenoj javnosti zagovarajući prava siromašne djece i omogućiti slobodno izražavanje mišljena djece i mladih koji žive u siromaštvu.

I za sam kraj, polazeći od pitanja u naslovu projekta: Kako prekinuti začarani krug siromaštva?, možda se najbolji odgovor krije u perspektivi i preporukama samih siromašnih mladih o mogućnostima ublažavanja učinaka siromaštva djece. 


\section{LITERATURA}

1. Abela, A. \& Berlioz, G. (2007). Support for parenting of children at risk of social exclusion. In: M. Daly (ed.), Parenting in contemporary Europe: A positive approach. Strasbourg: Council of Europe Publishing.

2. Ajduković, M. (2015). Indikatori dobrobiti i siromaštva djece u Hrvatskoj u doba krize: Kako prekinuti začarani krug siromaštva djece? Projektni prijedlog. Zagreb: Pravni Fakultet Sveučilišta u Zagrebu i Zaklada ADRIS (http://www.pravo.unizg. $\mathrm{hr} / \mathrm{scsr} /$ projekti/zaklada_adris).

3. Ajduković, M. (2016). Završna konferencija projekta: Indikatori dobrobiti i siromaštva djece u Hrvatskoj u doba krize: Kako prekinuti začarani krug siromaštva djece? Zagreb, veljača 2016.

4. Ajduković, M., Dobrotić, I. \& Matančević, J. (2017). Mogućnosti unapređenja socijalne politike u smanjivanju siromaštva djece: Perspektiva ključnih dionika. Ljetopis socijalnog rada, 24 (2), 309-356.

5. Ajduković, M., Matančević i Rimac, I. (2017). Siromaštvo djece iz perspektive stručnjaka: učinci i mogućnosti djelovanja. Ljetopis socijalnog rada, 24 (2), 277-308.

6. Akrap, A. (2015). Demografski slom Hrvatske: Hrvatska do 2051. Bogoslovska smotra, 85, 3, 855-881.

7. Baturina, D., Berc, G.\&Majdak, M. (2014). Nevidljivi problem - stvarni rizik: Ispadanje učenika iz srednjoškolskog obrazovanja. Revija za socijalnu politiku, 21 (1), 43-67.

8. Bradshaw, J. (2011). The well-being od children in the UK. Bristol: The Policy Press

9. Bradshaw, J. (2015). The well-being of children. Prezentacija. Zagreb: Ured UNICEF-a za Hrvatsku.

10. Bradshaw, J., Richardson, D. \& Ritakallio, V. M. (2007). Child poverty and child well-being in Europe. Journal of Children's Services, 2 (1), 18-36.

11. Crosnoe, R., Mistry, R. S. \& Elder, Jr., G. H. (2002) Economic disadvantage, family dynamics and adolescent enrollment in higher education. Journal of Marriage and Family, 64 (3), 690-702.

12. Čorkalo Biruški, D. (2014). Etički izazovi kvalitativnih istraživanja u zajednici: od planiranja do istraživačkog izvještaja. Ljetopis socijalnog rada, 21 (3), 393-423.

13. Čudina-Obradović, M., Obradović, J. (2006). Psihologija braka i obitelji. Zagreb: Golden marketing - Tehnička knjiga.

14. Družić Ljubotina, O. \& Kletečki Radović, M. (2011). Siromaštvo i socijalni rad: Koliko je siromaštvo doista »tema« socijalnog rada? Ljetopis socijalnog rada, 18 (1), 5-29.

15. Družić Ljubotina, O. (2009). Atribucija uzroka siromaštva i neke psihosocijalne značajke primatelja stalne socijalne pomoći. Doktorska disertacija. Zagreb: Pravni fakultet, Studijski centar socijalnog rada. 
16. Družić Ljubotina, O., Kletečki Radović, M. \& Ogresta, J. (2016). Slika podrške beskućnicima u Hrvatskoj. Zagreb: Gradski ured za socijalnu zaštitu i osobe s invaliditetom.

17. Družić Ljubotina, O., Sabolić, T. \& Kletečki Radović, M. (2017). Život obitelji s djecom u uvjetima siromaštva iz perspektive roditelja. Ljetopis socijalnog rada, 24 (2), 243-276.

18. Državni zavod za statistiku (2016a). Geografska raspodjela rizika od siromaštva i socijalne isključenosti za mala područja u Republici Hrvatskoj. Zagreb: Državni zavod za statistiku.

19. Državni zavod za statistiku (2016b). Upotreba interneta kod pojedinaca u 2016. Zagreb: Državni zavod za statistiku.

20. Duncan, G. J. \& Brooks-Gunn, J. (ed.) (1997). Consequences of growing up poor. NewYork: Russell Sage Foundation.

21. Europska komisija (2013). Commission Recommendation of 20 February 2013 Investing in children: Breaking the cycle of disadvantage. Preuzeto s: http://eurlex.europa.eu/legal-content/EN/TXT/PDF/?uri=CELEX:32013H0112\&from=EN. (28.06.2017).

22. Jordan, B. (2006). Well-being: The next revolution in children's services? Journal of Children's Services, 1 (1), 41-50.

23. Klarin, M., Proroković, A. \& Šimić Šašić, S. (2010). Doživljaj prijateljstva i njegovi ponašajni korelati u adolescenata. Pedagogijska istraživanja, 7 (1), 7-22.

24. Kletečki Radović, M. (2008). Teorija osnaživanja u socijalnom radu. Ljetopis socijalnog rada, 15 (2), 214-242.

25. Kletečki Radović, M. (2011). Siromaštvo i neki aspekti psihosocijalnog razvoja djece. Doktorska disertacija. Zagreb: Pravni fakultet.

26. Kleteči Radović, M. i Vejmelka, L. (2016). Učinak siromaštva na dobrobit i kvalitetu života djece-perspektiva djece i mladih. Završna konferencija projekta: Indikatori dobrobiti i siromaštva djece u Hrvatskoj u doba krize: Kako prekinuti začarani krug siromaštva djece? Zagreb, veljača 2016.

27. Konvencija o pravima djeteta. Preuzeto s: http://www.unicef.hr/upload/ file/300/150215/FILENAME/Konvencija_20o_20pravima_20djeteta.pdf, (20.6.2017).

28. Lansdown, G. (2010). The realisation of children's participation rights: Critical reflections. In: Percy-Smith, B., Thomas, N. (eds.), A handbook of children and young people's participation- perspectives from theory and practice. Routhledge, 11-23.

29. Linver, M. R., Brooks-Gunn, J. \& Kohen, D. E. (2002). Family processes as pathways from income to young children's development. Developmental Psychology, 38 (5), 719-734. 
30. Magadi, M. \& Middleton, S. (2007). Severe Child Poverty in the UK. London: Save the Children.

31. Matković, T. (2010). Obrazovanje roditelja, materijalni status i rano napuštanje školovanja u Hrvatskoj: Trendovi u proteklom desetljeću. Društvena istraživanja, 19 (4-5), 643-667.

32. Milas, G. (2009). Istraživačke metode u psihologiji i drugim društvenim znanostima. Jastrebarsko: Naklada Slap.

33. Miličević, F. \& Dolenec, D. (2009). Razvoj socijalne dimenzije u obrazovanju: Izvještaj za Hrvatsku. Zagreb: Institut za društvena istraživanja u Zagrebu.

34. Minujin, A., Delamonica, E., Davidziuk, A. \& Gonzalez, E. D. (2006). The definition of child poverty: A discussion of concept sand measurements. Environment and Urbanization, 18 (2), 481-500.

35. Olweus, D. (1998). Nasilje među djecom u školi. Zagreb: Školska knjiga.

36. Onwuegbuzie, A. J., Dickinson, W. B., Leech, N. L. \& Zoran, A. G. (2009). A qualitative framework for collecting and analyzing data in focus group research. International Journal of Qualitative Methods, 8 (3), 1-21.

37. Pećnik, N. (ur.) (2013). Kako roditelji i zajednice brinu o djeci najmlađe dobi u Hrvatskoj. Zagreb: Ured UNICEF-a za Hrvatsku.

38. Pećnik, N. (2003). Izvori socijalne podrške i zadovoljstvo podrškom. U: Raboteg-Šarić, Z., Pećnik, N. \& Josipović, V. (ur.), Jednoroditeljske obitelji: Osobni doživljaj istavovi okoline. Zagreb: Državni zavod za zaštitu obitelji, materinstva i mladeži, 170-189.

39. Pinkerton, J. \& Dolan, P. (2007). Family support, social capital, resilience and adolescent coping, Child and Family Social Work, 12, 219-228.

40. Rajhvajn Bulat, L. \& Ajduković, M. (2012). Obiteljske i psihosocijalne odrednicevršnjačkoga nasilja među mladima. Psihologijske teme, 21 (1), 167-194.

41. Redmond, G. (2008). Child poverty and child rights: Edging towards a definition. Journal of Children and Poverty, 14 (1), 63-82.

42. Ritchie, J. \& Spencer, L. (1994). Qualitative data analysis for applied policy research. In: Bryman, A. \& Burgess, R. (eds.), Analyzing qualitative data. London: Routledge.

43. Ridge, T. (2002). Childhood poverty and social exclusion: From a child's perspective. Bristol: Policy Press.

44. Srivastava, A. \& Thomson, S. B. (2009). Framework analysis: A qualitative methodology for applied policy research. Journal of Administration \& Governance, 4 (2), 72-79.

45. Šućur, Z. (2014). Stari i novi siromasi u hrvatskom društvu: empirijski uvid. Bogoslovska smotra, 84(3), 577-610.

\section{0 članci}


M. Kletečki Radović, L. Vejmelka, O. Družić Ljubotina: Učinak siromaštva na dobrobit i kvalitetu...

46. Šućur, Z., Kletečki Radović, M., Družić Ljubotina, O. \& Babić, Z. (2015). Siromaštvo i dobrobit djece predškolske dobi u Republici Hrvatskoj. Zagreb: Ured UNICEF-a za Hrvatsku.

47. Šućur, Z., Babić, Z., Urban, I. \& Baran, J. (2016). Struktura naknada, izdaci i korisnici programa socijalne zaštite u Republici Hrvatskoj. Izvješće u sklopu projekta »Sinergijski socijalni sustav«. Zagreb: Ministarstvo socijalne politike i mladih i UNDP u Hrvatskoj.

48. UNDP (2007). Kvaliteta života u Hrvatskoj:Regionalne nejednakosti. Zagreb: UNDP Hrvatska.

49. UNDP (2009). Mladi između obrazovanja i zapošljavanja: isplati li se školovati? Zagreb: UNDP Hrvatska.

50. UNICEF (2005). The state of the world of the children 2005-Childhood under threat. New York: UNICEF.

51. UNICEF (2007). Child poverty inperspective: An overview of childwell-being in rich countries Innocenti Report Card. Florence: UNICEF Innocenti Research Centre.

52. UNICEF (2008). Mišljenja i stavovi djece i mladih u Republici Hrvatskoj. Ured UNICEF-a za Hrvatsku.

53. UNICEF (2011). Analiza stanja prava djece ižena u Hrvatskoj. Zagreb: Ured UNICEF-a za Hrvatsku.

54. UNICEF (2014). Analiza stanja prava djece ižena u Hrvatskoj. Zagreb: Ured UNICEF-a za Hrvatsku.

55. UNICEF (2014). Children of the recession. The impact of the economic crisis on chiIdwell-being in rich countries. Innocenti Report Card 12. Florence: UNICEF Office of Research.

56. Vlada RH (2014). Nacionalna strategija za prava djece u Republici Hrvatskoj za razdoblje od 2014. do 2020. godine. Preuzeto s: www.mspm.hr. (2.7.2017.).

57. White, L. \& Rogers, S. J. (2000). Economic circumstance sand family outcomes: A review of the. 1990s. Journal of Marriage and Family, 62 (4), 1035-1051.

58. Wolf, W. (2007). The European perspective on child poverty. European Commission. DG Employment, Social Affairs and Equal Opportunities. Conference paper, Sofia.

59. Wright, M. O. \& Masten, A. S. (2006). Resilience processessin development: Fostering positive adaptation in the context of adversity. In: Goldstein, S. \& Brooks, R. B. (eds.), Handbook of resilience in children. New York: Springer, 17-37.

60. Zakon o socijalnoj skrbi $(2013,2014,2015,2016,2017)$. Narodne novine, 157/2013., 152/2014., 99/2015., 52/2016., 16/2017. 
Marijana Kletečki Radović

Lucija Vejmelka

Olja Družić Ljubotina

University of Zagreb

Faculty of Law

Department of Social Work

\title{
EFFECT OF POVERTY ON THE WELL-BEING AND QUALITY OF LIFE OF FAMILIES FROM THE PERSPECTIVE OF CHILDREN
}

\begin{abstract}
This paper presents the results of qualitative research with the objective of gaining insight into the effect of poverty on the well-being and quality of life of children living in the conditions of poverty in communities with different capacities for social resources. Specifically, the objective was to gain insight into the possibility of mitigating the effects of poverty on children from the perspective of children. Three focus groups were organised that included secondary school students from families using the right to guaranteed minimum remuneration. The students attend four-year (grammar school, professional school) or three-year (vocational school) secondary school programmes.

The results show that the children are aware of the adverse effects of the economic crisis on their own lives, the lives of their parents, and the family as a whole. They identify the specific aspects of life in which they experience the effects of material scarcity, such as the basic living conditions, education, health, peer relations, free time, access to information, and the opportunity to express their own opinions and convictions. In their life, they rely on the informal sources of support and emphasize the responsibility of society and the state in mitigating the consequences of poverty on the life of children and their families. Specific differences were detected in terms of whether children live in poorer or richer communities. Children who live in a poorer community point to even more modest living conditions, opportunities for education and the organisation of leisure, and the substantially lowered availability of many services. Children who live in a richer community emphasize the importance of education for escape from poverty.

This is the first research that included poor children who voiced their personal experiences to deepen the understanding of how it is to be growing up in poverty and its effects on the well-being of children. Via the inclusion of their perspective, the children were able to express their opinion and cast their "vote" concerning this unfavourable social problem for themselves personally and for society as a whole.
\end{abstract}

Key words: poverty of children, well-being, poorer and richer communities, perspective of children.

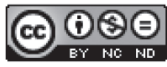

Međunarodna licenca / International License:

Creative Commons Attribution-NonCommercial-NoDerivatives 4.0.

\section{2 članci}

